\title{
Article \\ The Search of St. Peter's Memory ad catacumbas in the Cemeterial Area ad Duos Lauros in Rome
}

\author{
Liberato De Caro $^{1}$ (D), Fernando La Greca ${ }^{2}$ and Emilio Matricciani ${ }^{3, *(D)}$ \\ 1 Istituto di Cristallografia, Consiglio Nazionale delle Ricerche (IC-CNR), 70126 Bari, Italy; \\ liberato.decaro@ic.cnr.it \\ 2 Dipartimento di Studi Umanistici, Universita degli Studi di Salerno, 84084 Fisciano, Italy; flagreca@unisa.it \\ 3 Dipartimento di Elettronica, Informazione e Bioingegneria, Politecnico di Milano, 20133 Milano, Italy \\ * Correspondence: emilio.matricciani@polimi.it
}

check for updates

Citation: De Caro, L.; La Greca, F.; Matricciani, E. The Search of St. Peter's Memory ad catacumbas in the Cemeterial Area ad Duos Lauros in Rome. Heritage 2021, 4, 479-506. https://doi.org/ $10.3390 /$ heritage4010029

Received: 29 January 2021

Accepted: 2 March 2021

Published: 6 March 2021

Publisher's Note: MDPI stays neutral with regard to jurisdictional claims in published maps and institutional affiliations.

Copyright: (c) 2021 by the authors. Licensee MDPI, Basel, Switzerland. This article is an open access article distributed under the terms and conditions of the Creative Commons Attribution (CC BY) license (https:/ creativecommons.org/licenses/by/ $4.0 /)$.

\begin{abstract}
The purpose of our study is to research Peter's memory ad catacumbas. According to the Depositio Martyrum - a document of the late Emperor Constantine period-there was no memory of the first St. Peter's Basilica on the Vatican Hill. We start with a critical analysis on the Roman Basilica attributed to Emperor Constantine in Liber Pontificalis, then we deepen the search of Peter's memory in the catacombs of the Sts. Marcellinus and Peter (ad Duos Lauros), also known as Tor Pignattara. Indeed, the basilica and mausoleum built in this cemeterial area are the only buildings attributable, with certainty, to Emperor Constantine, who wished to be buried in the mausoleum, close to an apostle. Besides some striking archeological finds on Peter's memory already discovered near a particular cubicle in these catacombs, a geometrical and mathematical study of the unusual architectonic characteristics of the basilica and mausoleum of Tor Pignattara shows that the buildings were part of a single architectonic plan, very likely designed for coding data useful to locate Peter's burial site unambiguously, in the area of the cubicle mentioned.
\end{abstract}

Keywords: Saint Peter's tomb; Catacombs of Sts. Marcellinus and Peter; Emperor Constantine; Tor Pignattara's basilica and mausoleum

\section{Introduction}

Since the 4th century, the Catholic Church has venerated Peter's memory in the Vatican. This memory was confirmed about 80 years ago, in an excavation campaign, when the archeologists Ferrua, Apollonj Ghetti, Josi, and Kirschbaum found, just beneath the altar in St. Peter's Basilica, a little monument of the 2nd century, which recalled Peter [1] The monument is a small aedicule, the "trophy" mentioned in a letter of a Roman priest Gaius, at the time of Pope Zephyrinus (199-217) (Eusebius of Caesarea, Historia Ecclesiae, $2.25,5-7)$. The discovery was important because the niche had remained at the center of the basilica of the 4th century, and later in the actual St. Peter's Basilica. Nevertheless, this discovery is one of the most controversial of the 20th century.

The discovery concerns the tomb, not Peter's remains. The four archeologists concluded they had found the site of Peter's burial, or at least one of the sites of his burial, because they had not found human remains attributable at the apostle [1]. However, a sudden and unexpected fact occurred in the 1960s. After several years of investigating Christian graffiti in the area of Peter's tomb, the epigraphist Guarducci, who had not participated in the excavations campaign, announced she had identified Peter's bones [2,3]. The modality of the discovery, however, raised many doubts among the experts. A workman who had participated in the excavations campaign had indicated to her a group of bones found during the campaign, belonging to three skeletons, but forgotten inside a box in the excavations' warehouse for more than 10 years, until 1953. The story produced a scathing debate between Guarducci and Ferrua [4-8], who did not agree with her conclusions. 
To prove her discovery, Guarducci declared she had found the proof that they were Peter's bones in a little fragment of red plaster, found to the right of a niche excavated in the so-called "red wall", with a few engraved letters $[9,10]$. She saw the Greek expression "Petr[os] eni", i.e., "Peter is here", a kind of proof of his burial, an indirect proof that one of the three skeletons discovered and studied by the anthropologist Correnti [2,3] was attributable to Peter.

However, Guarducci's epigraphic proof was very weak so that it was challenged very soon by Ferrua [4-8]. In fact, it would have been strange that, in the 4th century, to support the presence of the Chief of the Apostles, there was only a poor graffiti on a small area of the plaster, and not a more important epigraph, on marble, ordered by Constantine himself for the importance of the relics there buried. After so many years, with all protagonists of the debate now dead, it is clear that the argument is not settled yet [11]. Indeed, even admitting that Peter's remains are those found in St. Peter's Basilica, they have not been always there.

Today, the most accepted opinion is that Peter's remains were moved in one of the Roman catacombs [12,13], because there is another ancient memory of St. Peter ad catacumbas, dated at the end of the Emperor Constantine period (306-337). In fact, in the Chronograph (i.e., Roman Calendar) of the year 354, in which we find the Depositio Martyrum of 336, St. Peter's commemoration was ad catacumbas, not in the Vatican hill, while St. Paul's was already sited in Via Ostiensis, where the St. Paul's Basilica was built [14] (pp. 337-338). Carcopino, just starting from the Depositio Martyrum, suggested that Peter's remains in the year 258 - the year of the consulate of Tusco and Basso, named in the Depositio Martyrumwere moved from the Vatican caves to the catacombs (ad Catacumbas). Today, this is the most accepted opinion [13].

To explain this ancient memory of St. Peter, it was also suggested that the catacombs in Via Appia have kept, for a certain period, both Peter's and Paul's remains, but the archeological evidence seems to exclude this hypothesis [15]. In St. Sebastian's catacombs, there is only a trace of the refrigeria in honor of Peter and Paul, in other words, of the funerary rituals, very popular, carried out every year on June 29 (both saints are still today celebrated by the Catholic Church on this day). This should be the origin of the Memoria Apostolorum in St. Sebastian's catacombs, i.e., a funerary ritual very likely established around the year 258, according to the date of the consuls Tusco and Basso mentioned in the Depositio martyrum [15]. Conversely, the contemporaneous presence of the remains of the two apostles in St. Sebastian's catacombs is a vexata quaestio [16] (p. 67), because the only indirect proof of this presence-during the persecutions of Emperor Valerianus-traces back to medieval epigraphic collections of a poem of Pope Damasus, dedicated to the two apostles, now lost [17]. Moreover, the archeological excavations have not confirmed the presence of remains and burials attributable to Sts. Peter and Paul [18]. Thus, the many graffiti dedicated to Peter and Paul, found in the cemeterial area of St. Sebastian's catacombs, can be explained by the funerary ritual previously mentioned.

In the years 1948-1949, to solve the enigma of St. Peter's tomb, at the end of the excavation campaign in the Vatican caves-because no traces of St Peter's relics had been found-some important personalities of the Vatican even approached an Italian mystic, Maria Valtorta, in the attempt to get some further information about the site of Peter's remains [11].

The purpose of our study is to research St. Peter's memory ad catacumbas, in the catacombs of Rome [19]. In other words, we look for the last catacomb that has housed, or may still house today, St. Peter's remains. To achieve this goal, we first analyze ancient textual sources for directing our research towards a specific cemeterial area (archaeological research) which - as we will see-is definitely that of the Sts. Marcellinus and Peter catacombs. Figure 1 summarizes the planning of our research. 


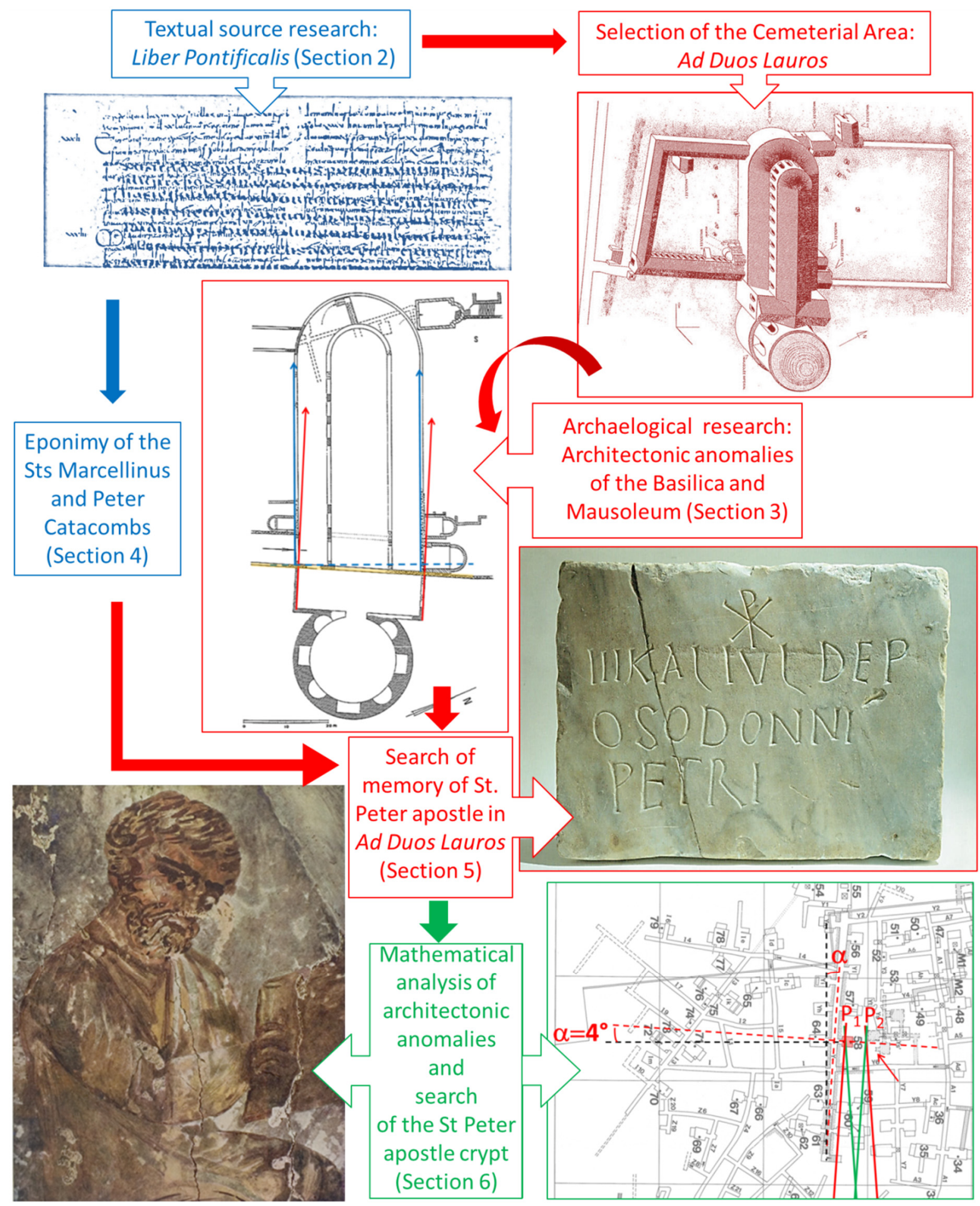

Figure 1. Planning of the research. At the top left corner an image of the folio $42 \mathrm{v}$ of the Manuscript IV.A.8 of the Liber Pontificalis (https:/ / elmss.nuigalway.ie/catalogue/741, accessed on 22 February 2021). The other images of the figure are explained in the indicated sections.

We start first with a critical analysis of what is reported in Liber Pontificalis on the Roman basilicas attributed to Emperor Constantine (Section 2), because very likely he built one of them very close to the site where St. Peter's memory and remains were located. Following this trace, we then deepen the search of St. Peter's memory in the catacombs of the Sts. Marcellinus and Peter in the suburbs of Rome-known today as Tor Pignattara (in the ancient Via Labicana) - because its basilica and mausoleum are the only buildings 
attributable with certainty to Emperor Constantine. Section 3 summarizes the architectonic anomalies of the basilica and mausoleum erected in the catacombs of Sts. Marcellinus and Peter. Section 4 discusses the true eponymy of the catacombs of Sts. Marcellinus and Peter. Section 5 is devoted to the search of the memory of St. Peter the Apostle in the catacombs of Sts. Marcellinus and Peter. Section 6 reports a geometrical and mathematical study of the unusual architectonic characteristics of the basilica and mausoleum of Tor Pignattara, and shows that the buildings were part of a single architectonic plan, very likely designed for communicating important data on Peter's burial site; at least, this is our conjecture. The mathematical analysis supports the hypothesis that St Peter's memory ad catacumbas refers to this cemetery. Finally, Section 7 summarizes the main findings and draws some conclusions, which may lead archaeologists to validate, with excavation campaigns, our findings and conjecture.

\section{The Roman Basilicas Attributed to Emperor Constantine in the Liber Pontificalis}

The only written source concerning the Constantinian basilicas built in Rome is Liber Pontificalis (Book of Popes), an editorial compilation which dates back to the 6th century [14] (p. 325). According to the interpretation commonly accepted by scholars-already supported by Duchesne, a 19th century editor of Liber Pontificalis (LP), and lately by other scholars as Krautheimer [20]—-the editors of Liber Pontificalis transcribed archival documents belonging to a historical period prior to several centuries [14] (p. 329). A more ancient source than Liber Pontificalis, the Itinerarium Burdigalense, lists the stops of a pilgrimage from Gaul to Jerusalem, which occurred in the years 333-334, and describes the basilicas just built by Constantine in Jerusalem, mentioned also by Eusebius of Caesarea. For the Roman basilicas, however, there are no contemporary documents of the period when they were built.

Neither Eusebius nor Athanasios, Christian authors of the 4th century, mention any important building erected by Constantine in Rome, such as a basilica. For this reason, historians today are cautious in attributing to him what is reported in Liber Pontificalis [14] (pp. 329-330), [21,22]. Therefore, let us start by summarizing the information given in it about the Constantinian basilicas, by considering the most recent historical studies.

Liber Pontificalis is a collection of biographies of popes, written in Rome since the beginning of the 6th century. The first 33 biographies are synthetic. The 34th biography, dedicated to Sylvester I, pope in the years 314-335 and contemporary of Constantine, is quite detailed.

In Figure 2, we show, schematically, the site of the Roman basilicas allegedly built by Constantine, with reference to the Aurelian Walls and the nearby consular roads [23].

The first basilica mentioned is St. Salvatore (St. Savior) [22]( p. 44), today known as San Giovanni in Laterano (St. John in Lateran), considered the Constantinian basilica per antonomasia (LP, XXXIV 9-12) because of its large dimensions [22] (pp. 57-61) and its site within the Aurelian Walls. It might have been built by Constantine [22] (p. 44), [14] (p. 331), but Barbero has noted that Eusebius, both in his Historia Ecclesiastica and in Vita Constantini, insists in saying that the victorious Constantine wanted to build a trophy to show everybody Who was responsible for his victory. Therefore, he ordered to build a statue of himself - to be erected in the most frequented site of Rome-with a "salvific sign", very likely a cross, in his hand to indicate Who was to be praised. Barbero observes that it is not possible that Eusebius, a very attentive observer, had ignored the construction of a large basilica by Constantine, much more important than a statue [14] (p. 336). 
1. St. Salvatore (S. John in Lateran)

2. St. Peter (Vatican)

3. St. Paul (Via Ostiense)

4. Basilica of the Holy Cross in Jerusalem

5. St. Agnes and Mausoleum of St. Constance (Via Nomentana)

6. St. Lawrence (Via Tiburtina)

7. Sts. Peter and Marcellin, and Mausoleum of St. Helena (Via Labicana)

8. St. Sebastian (Via Appia)

Via Nomentana

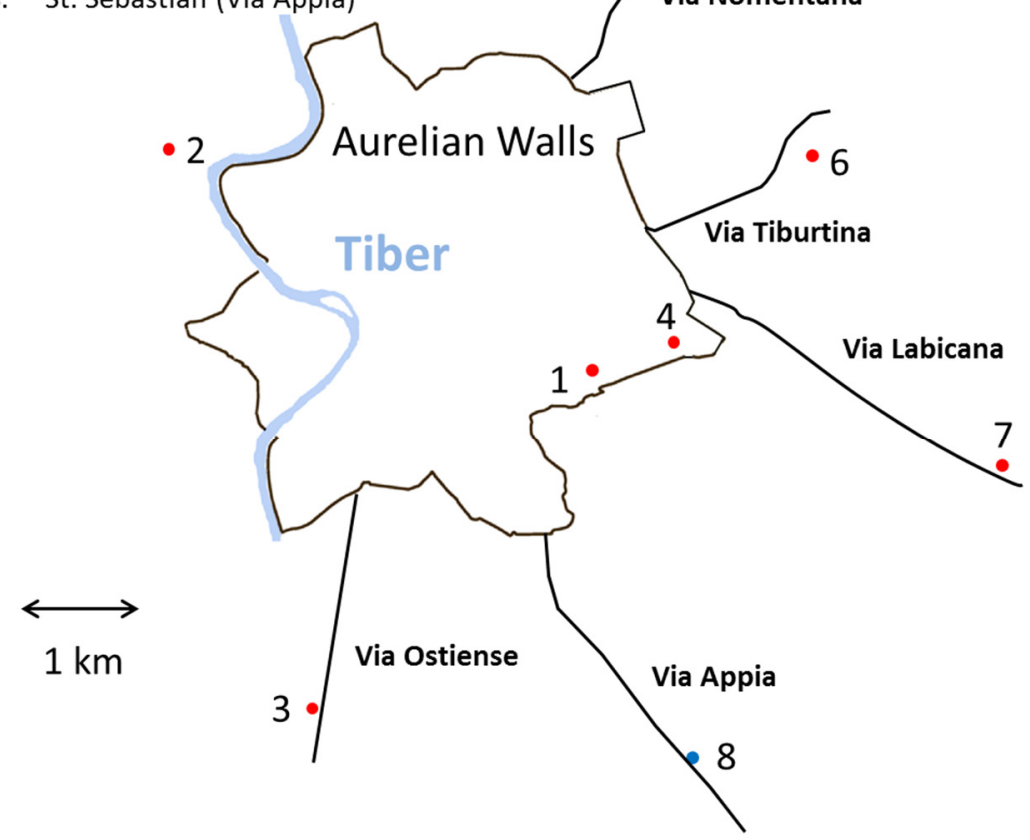

Figure 2. The Roman basilicas attributed to Emperor Constantine in the Liber Pontificalis (red bullet) and the Basilica of Sts. Apostles (St. Sebastian), not mentioned in the Liber Pontificalis (blue bullet).

The second Basilica mentioned is St. Peter's (LP, XXXIV 16-20), erected on the Vatican Hill (Figure 2). Besides Liber Pontificalis, other sources useful for deciding whether the basilica was really built by Constantine, or by his son, are three epigraphs, today lost [14] (p.338). However, the historical reliability of this epigraphic evidence is not uniquely accepted. To clarify this point, Barbero analyzes the inscription in the mosaic of the apse: "Seat of justice, house of faith, palace of chasteness / is this you see, all pervaded of mercy, / which is glad of the sublime virtue of the father and of the son / and makes equal his author to the fame of the parent" [14] (p. 339). The inscription seems to affirm that the author of the basilica, just because of this construction, is equal to his parent, who might have been either Constantine or Constantius I (Constantine's father). Barbero, on this point, comments that the glory of Constantine already in 312 was immensely greater that his father's glory, and that it is not possible to imagine that a mature man of such a large success would have shared it with his father. Moreover, this behavior would have been against the image of himself that Constantine wanted to establish. On the other side, it is known that his sons were very interested in affirming that they had equaled their father's glory [14] (p. 340). These findings support the hypothesis that St. Peter's Basilica might have been started by Constantius II (337-350) [4] (p. 340) and finished by Constantine II (337-361) in 350, as recently discussed by Logan [24].

Moreover, if we observe that St. Peter's Basilica is not mentioned among the sites of cult due to martyrs-in fact, St. Peter's cult is referred to as in catacumbas and St. Paul's to Via Ostiensis-it should be concluded that the Basilica was not yet finished at half of the 4th century [14] (pp. 337-338) and, very likely, not before the year 336 because the Depositio Martyrum should have been written in 336 [25]. St. Peter's Basilica was erected 
on the Vatican Hill where the Trophy of Gaius was found in the 1940s, as recalled in the Introduction, and it is not yet established whether the Trophy of Gaius was erected only as a memory of the site where Peter was martyred, or where his remains were also buried [11].

The third Constantinian basilica mentioned is St. Paul's (LP, XXXIV 21), now known as St. Paul outside the Walls (San Paolo fuori le mura, Figure 2). Because the archeological excavations have shown that it was built at the time of Theodosius, Emperor of the Eastern Roman Empire in the years 379-392, we are certain that the documental evidence about this basilica has no historical value, but only editorial [14] (p. 340).

The next basilica mentioned is St. Cross (Santa Croce) (LP, XXXIV 22) but, very likely, it is not a Constantinian basilica because recent excavation campaigns [26] have shown that it was an enlargement of a villa belonging to the Severi family at the half of the 4th century [14] (p. 341).

The next basilicas are those in cemeteries, the most important for our study. We must exclude, however, two of them because they are not Constantinian, namely St. Agnes in Via Nomentana (LP, XXXIV 23), where there is the mausoleum of St. Constance (Santa Costanza) (Figure 2), Constantine's daughter, likely built around the year 340, and St. Lawrence (San Lorenzo), in Via Tiburtina (LP, XXXIV 24-25), generally considered of later construction. Only one possible Constantinian basilica is left, that located in the ancient Via Labicana (Tor Pignattara), dedicated to Sts. Marcellinus and Peter (Figure 2), the martyrs of the 4 th century, with the annex mausoleum (LP, XXXIV 26-27). This is the conclusion largely shared by scholars and archeologists, because of the masonry used and a coin found in the lime of the basilica, which allow us to date it as truly Constantinian [14] (pp. 344-346).

Finally, we also have to consider the basilica of St. Sebastian (blue bullet in Figure 2), although not mentioned in Liber Pontificalis [14] (p. 347). Already the Emperor Maxentius (306-312) might have started the construction, in Via Appia, of the first basilica dedicated to Sts. Apostles (today, St. Sebastian) or, maybe, granted the land of imperial property to build, under Constantine, the most ancient Roman basilica [22] (p. 41). According to tradition, during the persecutions of Valerianus, in the 3rd century, the remains of Sts. Peter and Paul were hidden in the catacombs of the area and there revered for about 50 years. Later, however, the veneration of St. Sebastian prevailed in naming the cemetery and the basilica after him, very likely because remains of the apostles were never buried there, as confirmed by archeological excavations [18].

In synthesis, the only basilica that, with certainty, can be attributed to Constantine is that erected in the area today known as the catacombs of Sts. Marcellinus and Peter (Tor Pignattara). Moreover, just attached to the basilica, Constantine erected the mausoleum, now known as the Mausoleum of St. Helen, for burying his mortal remains. It is not a case that the access to the Mausoleum of St. Helen was located to the West, directly connected to the narthex of the basilica [22] (p. 45). Indeed, this mausoleum was built for receiving Constantine' mortal remains [22] but, when he moved the capital of the Roman Empire from Rome to the new city (Nova Roma) Constantinople in the year 330, the mausoleum became the sepulcher of his mother, who died in 328. It must be noted that Constantine was later buried in a mausoleum close to a church dedicated to the Saints Apostles (Apostoleion) in Constantinople [22]. Eusebius explicitly writes that he built Saints Apostles (Vita Constantini, IV 58-60, 70-71). It is plausible that the mausoleum erected in the catacombs of Marcellinus and Peter had to be very close to some important mortal remains hidden there and related to the memory of one of the Apostles. However, Marcellinus and Peter had been martyred, with many other Christians, under Diocletian's persecutions, just before Constantine became Emperor.

According to some scholars, Constantine would have built the mausoleum in that area for destroying the sepulcher of the Equites singulares Augusti who, in the decisive battle of Ponte Milvio, were allied with his adversary Maxentius. This hypothesis could be supported by many archeological finds concerning the Equites singulares recovered 
during the excavation campaigns conducted in the 1940's by Deichmann and Tschira [23] (pp. 87-88), [27], and later by Guyon [28].

However, even admitting the desire of revenge, the necropolis of the Equites Singulares would have been, in any case, destroyed for erecting the basilica, built-according to Guyon [23] (p.89) [28] - with exact correspondence with some perimetric walls of the cemetery of the Equites Singulares. According to Deichmann and Tschira, the basilica was erected before the mausoleum, in the years 320-325, and the mausoleum was outside the cemetery of the Equites Singulares [27] (p. 64), even though the unity of the complex cannot be excluded [23] (p. 167), [29] (pp. 45-46]. The mausoleum could have been built in occasion of the twentieth year of Constantine's reign (Vicennalia), in 326 [18] (pp. 45-46) [22] (p. 44).

\section{The Inexplicable Asymmetry and out-of-Standard Size of the Basilica and Mausoleum Erected in the Catacombs of Sts. Marcellinus and Peter}

The complex of the basilica and mausoleum erected in the catacombs of Sts. Marcellinus and Peter show an inexplicable asymmetry and out-of-standard size, not justifiable in Rome, homeland of great architects and constructions engineers, who built perfectly symmetric Basilicas for civil use, taken later as models for the Christian basilicas.

As shown in Figure 3a, there is an evident asymmetry between the narthex and the mausoleum on one side (blue arrows) and the basilica on the other side (red arrows), evidenced by a rotation angle of about $4^{\circ}$, clearly visible in the axonometric projection of Figure $3 \mathrm{~b}$. The hypothesis put forward to explain this anomaly, not present in other basilicas of the 4th century [23], is that the mausoleum and the narthex were oriented parallel to Via Labicana [23] (p. 92) — shown in Figure 3b—that is, along the direction of the red arrows. The entrance front-wall of the basilica, on the contrary, would have followed the ancient wall of the Equites Singulares cemetery, which is not parallel to Via Labicana [23] (p. 92), evidenced in yellow in Figure 3a. Moreover, the direction of the basilica's apse is not perpendicular to this wall, as evidenced by the blue dashed line. To explain this further anomaly, it is said that the designers oriented the apse along the direction of the blue arrows to avoid that the foundations of the basilica were laid just on the crypt underground [23] (p. 92), dedicated to the martyrs Marcellinus and Peter, shown in the upper right corner in Figure 3a.

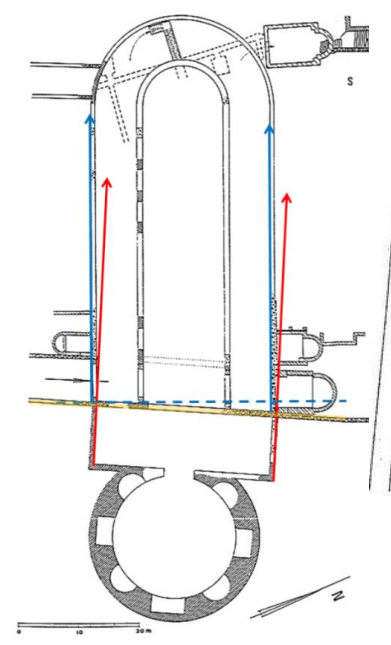

(a)

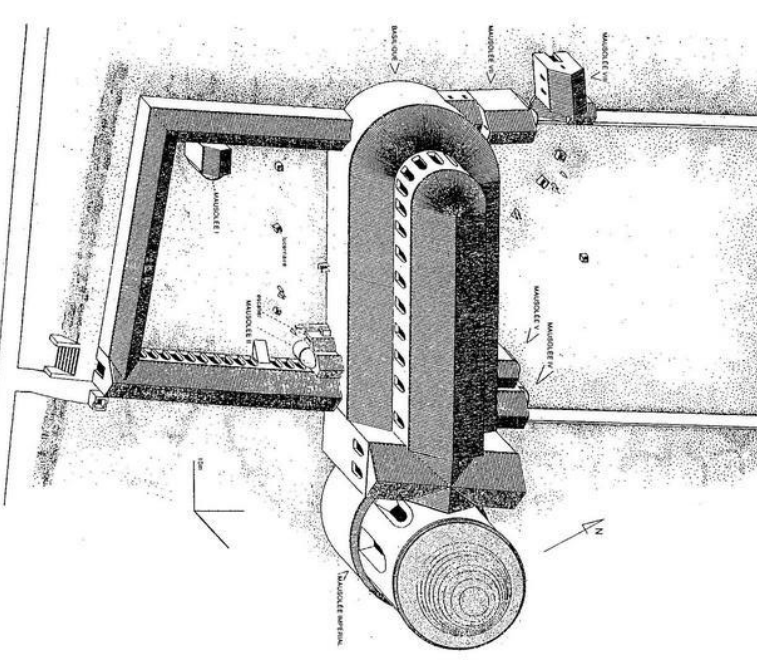

(b)

Figure 3. (a) Planimetry of the basilica of the Sts. Marcellinus and Peter. On the original figure [30], we have superposed the colored arrows to point out the different orientations of the narthex (red) and the apse of the basilica (blue). The yellow line represents the wall of the ancient cemetery of the Equites Singulares Augusti. The crypt of the Sts. Marcellinus and Peter is in the upper right corner. (b) Axonometric projection of the complex [28]. Via Labicana is on the left. 
However, as noticed by Barbero [14], the hypothesis put forward to explain the anomaly of this complex is not shared by all scholars and it is disclaimed by the fact that the cemetery of the Equites Singulares Augusti, according to many archeological finds, should have been located in the area but not below the basilica and mausoleum. If the cemetery were below the basilica and mausoleum, then Constantine would have committed an act of blasphemy, without precedents in Rome, which is out of the question [14] (p. 334). Therefore, this unacceptable hypothesis is more an ad hoc explanation formulated to explain the evident asymmetry, in a world of architectonic order, that is otherwise inexplicable.

As shown in Figure 4, if the apse (dashed red lines) were not rotated by about $4^{\circ}$ with respect to the narthex (dashed red lines), the basilica would have practically the same area of that really built (blue lines), and the foundations of the basilica would have avoided the crypt (violet area). The reduction of the red area compared to the blue area is a negligible $5 \%$, which would have been largely acceptable if we consider how much easier it would have been to build the narthex and basilica perfectly aligned, with $90^{\circ}$ angles, not to mention the beauty of the regular classical model of the Roman basilica of civil use.

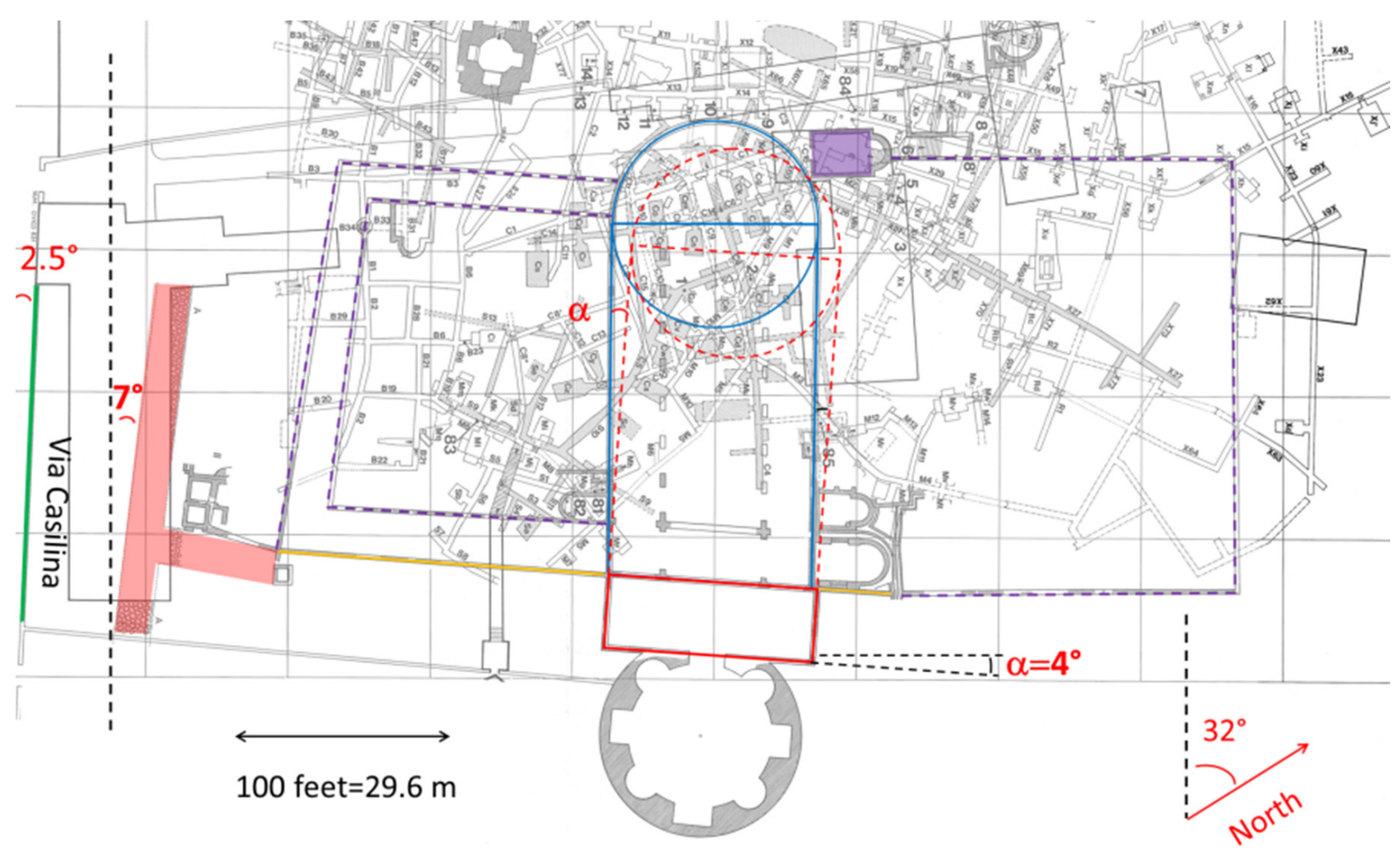

Figure 4. Planimetry (detail) of the catacombs of the Sts. Marcellinus and Peter, from the Archivio della Pontificia Commissione di Archeologia Sacra (PCAS) [31], rotated $90^{\circ}$ counterclockwise. Detail of the area around the basilica of the Sts. Marcellinus and Peter (blue). The dashed violet lines represent the walls of the perimeter of the complex (see Figure $3 b$ ). $\alpha=4^{\circ}$ is the angle between the short side of the narthex and the long side of the basilica. The dashed red lines show the hypothetical basilica if the narthex and apse were not rotated by $4^{\circ}$. The yellow line represents the wall of the ancient cemetery of the Equites Singulares Augusti. The crypt of the martyrs Marcellinus and Peter is drawn in violet. The red stripes to the left indicate the old access road to the complex. The green line represents the modern Via Casilina. One Roman foot equals $0.296 \mathrm{~m}$ [32].

Moreover, the hypothesis that the basilica was built parallel to the ancient Via Labicana must be excluded, because the ancient access road to the basilica, shown in red on the left in Figure 4, is not parallel to the apse of the basilica. Indeed, Via Labicana forms an angle of about $7^{\circ}$ with respect to the vertical reference line (black dashed line in Figure 4), and the apse of the basilica forms an angle of $6^{\circ}$ with respect to the ancient road. Moreover, 
as shown in the planimetry of the catacombs available from the Archivio della Pontificia Commissione di Archeologia Sacra (PCAS), and published in [31], besides the crypt of the martyrs Marcellinus and Peter, there are many other cubicles which are located beneath the area of the basilica. In spite of this, the foundations were built right there to produce a "striking" planimetry, outside the order, symmetry, and standards of Roman architecture.

Now, a few crucial questions arise: (a) Why this asymmetry? Why did Constantine not erect his mausoleum on the Vatican Hill, where the Trophy of Gaius had been found? Why was the catacombs area ad Duos Lauros in the ancient Via Labicana so important? Certainly not because of the recent martyrs of the 4 th century, Marcellinus and Peter. In the next Sections we try to answer these questions.

\section{The Eponymy of the Catacombs of the Sts. Marcellinus and Peter}

The cemetery of Sts. Marcellinus and Peter was located close to the ancient Via Labicana (Figure 2), to the North-now near Via Casilina - which originally started at Porta Esquilina, where the Arch of Gallieno is now located, at the Servian Walls, not shown in Figure 2. It is at about two Roman miles (about $3 \mathrm{~km}$ ) away from the Aurelian Walls, built in the 3rd century. These catacombs aroused archeological interest towards the end of the XIX century $[33,34]$, but had been partially explored more than a century before by A. Bosio [35]. The catacombs extend in a vast area of about 3 hectares, with at least $5 \mathrm{~km}$ of galleries deployed in two levels [36].

Originally, the cemetery was named ad Duos Lauros (at the two laurels) and, after Constantine, ad St Helenam, for the presence of the grand Mausoleum, whose ruins are still visible. The area was also referred to as sub Augusta and in Comitatu, because of a close imperial villa belonging to Constantine.

The medieval itineraries recall several groups of martyrs buried in the cemetery: Besides Marcellinus and Peter, also Tiburzius, Gorgonius, the Four Crowned (Quattro Coronati), a group of several tens of martyrs killed during Diocletian's persecutions.

Marcellinus, a priest and Peter, a laic and exorcist, were martyred at the beginning of the 4th century in Via Cornelia, in the locality known as Sylvia Nigra and after their death called Sylva Candida. Pope Damasus learnt the details of their death directly from their executioner, as he wrote in the ode dedicated to their memory and laid down in the crypt. The ode is lost, but its content is known [33] (p. 261). It starts as: "Marcelline tuos pariter Petre nosce triumphos. Percussor retulit Damaso mihi cum puer essem ... ", that is: "Marcellinus, and equally you Peter, be proud of your trophies [e.g., their deaths]. The man who hit you with the sword told me, Damasus, when I was a kid ... ". Let us note the "obvious" order of the names: First Marcellinus, because he was a priest, then Peter, a laic, which is less important in ecclesiastic hierarchy.

From the Acts of their martyrdom [33] (p. 261), we know that their bodies were buried near the body of St. Tiburzius. However, even if there are so many martyrs in this cemetery, the area is known as the catacombs of Sts. Marcellinus and Peter. Because many catacombs were excavated before their death, the cemetery could have been named and dedicated to someone else.

In the medieval Itineraries, which guided the pilgrims visiting the principal sites of Christian martyrs in Rome, we do find the indication of the two martyrs, but with the order of their names switched, first Peter followed by Marcellinus. Marucchi lists all martyrs of six medieval Itineraries in a long note in his 1905 book dedicated to the Roman catacombs [33] (p. 257). It is to be noted that, except for one case, Peter is always listed before Marcellinus. It may be either an error, repeated however in all medieval Itineraries, or it may indicate something more profound.

After this remark, now let us discuss the question of to whom the Basilica was dedicated. Liber Pontificalis was edited a few centuries after the death of Constantine, and we have several slightly different copies edited in different times. In the most recent ones, 11th century, in the biography of pope Sylvester [LP, XXXIV, n. 26], we find both orders of the names: Marcellinus and Peter, or vice versa [37] (p. 65). However, the oldest version of 
the manuscript we have, dated at the end of the 7th century, states that the Basilica was dedicated to "Beato Petro cum Marcellino, martyribus" [37] (p. 63, note 3), that is "to Blessed Peter with Marcellinus, martyrs".

The manuscript is the Neapolitanus IV.A.8, preserved in Biblioteca Nazionale of Naples (Italy), coming from the monastery of Bobbio, Northern Italy, founded in 614 by St. Colombanus. The codex is a palimpsest in which Liber Pontificalis is written in the last 8 pages (foll. 40-47). A part of fol. 42 is shown in Figure 1. This codex establishes a secure date ante quem: that is, Liber Pontificalis was certainly written before the end of the VII century. For the date post quem, Duchesne, who edited the classical edition in the years 1886-1892 [38], suggests that it was written at the beginning of the 6th century. Mommsen, in the edition of 1898 [37], suggests the beginning of the VII century, after Pope St. Gregory the Great. In other words, the manuscript Neapolitanus IV, A, 8 can be considered the oldest edition available of Liber Pontificalis, therefore written, at most, about a century and a half after its first edition.

Let us note that in the whole Liber Pontificalis, the expression "Beato Petro" is only used to indicate St. Peter the Apostle, the first pope. Therefore, we should conclude that in its oldest edition, the basilica ad Duos Lauros was dedicated to St. Peter the Apostle, martyred with Marcellinus, and not dedicated to Marcellinus and Peter, as reported in later editions. Now, as discussed previously, the basilica ad Duos Lauros is the only Roman basilica attributable to Constantine, built in the years 320-325 at about the same time of the mausoleum, built between 326 and 330 [22]. The question that now arises is why Constantine built it in that particular cemeterial area, and why it was dedicated to Beato Petro, that is, to St. Peter the Apostle.

In the Roman Calendar of 354, the commemoration of St. Peter was «ad catacumbas» and not on the Vatican Hill, while that of St. Paul was already in Via Ostiensis where the basilica dedicated him was built [14]. According to literary and archeological evidence, since the half of the 2nd century, the commemoration of St. Peter and St. Paul was held jointly on 29 June in Via Ostiensis (the refrigeria), not in the site where both had been buried [15]. Therefore, it can be conjectured that Peter's memory ad catacumbas might refer to the catacombs of Marcellinus and Peter. It could also be conjectured that his body was buried there, because in the Depositio Martyrum there is no mention of the ager Vaticanus (i.e., the Vatican Hill). Moreover, in the catacombs of St. Sebastian, there are no archeological traces that might confirm the simultaneous presence of the remains of both apostles.

In summary, Constantine should have erected the basilica and the mausoleum ad Duos Lauros because he wished to be buried close to the apostle Peter as, in a way, he managed to do in Constantinople. This conjecture would justify why in the oldest editions of the Liber Pontificalis the order is Peter and Marcellinus. Peter's remains should have been hidden in the second half of the 3rd century, to avoid the profanation of his remains during the persecutions of Valerianus, or at the beginning of the 4th century during the persecutions of Diocletian. Carcopino, according to the Depositio Martyrum, suggests that his remains in the year 258-year of the consulate by Tusco and Basso, mentioned in the Depositio Martyrum - were moved from the Vatican Hill to the catacombs, ad catacumbas, a hypothesis that today is still the most accepted [13].

Our analysis leads to the following hypothesis: The catacombs referred to as ad catacumbas for this ancient Peter's memory are those of Sts. Marcellinus and Peter (ad Duos Lauros). The catacombs of St. Sebastian's, should be excluded because no archeological evidence has been found there on the remains, or crypts, either of Peter or Paul, but only evidence that both apostles were commemorated together there, on 29 June during the refrigeria rituals $[9,15]$. After the foundation of Constantinople and the fall of the Western Roman Empire, the memory of the presence-clearly hidden —of Peter's remains in the catacombs ad Duos Lauros, was very likely lost and later, in the less ancient medieval copies of the Liber Pontificalis, the Constantinian basilica and the catacombs were dedicated to Marcellinus and Peter, martyrs of the 4th century, whereas in the oldest copy, the catacombs seem to be dedicated to the apostle Peter (Beato Petro).

In the next section, we bring striking evidence that supports our hypothesis, and in Section 6 we show that the architects and engineers of the complex basilica plus mausoleum, 
erected simultaneously in the cemeterial area ad Duos Lauros, might have coded in it the information necessary to locate a precise position, within the cemeterial area, where Peter's remains might have been hidden and might be still today.

\section{The Memory of St. Peter the Apostle in the Catacombs of Sts. Marcellinus and Peter}

In this section, we summarize what the archeologists have found regarding St. Peter's memory in the catacombs of Sts Marcellinus and Peter.

The first finding is a striking sepulchral epigraph (Figure 5) that may refer to Peter's burial, but found in an unexpected place, namely in the catacombs of Sts. Marcellinus and Peter. It has been observed [16] (p. 69) that if the epigraph alluded to the liturgical feast of St. Peter, it should be explained why Peter would have been remembered in a catacomb of the ancient Via Labicana. With our conjecture, the epigraph was there because, maybe for only a period of time, Peter was buried in these catacombs.

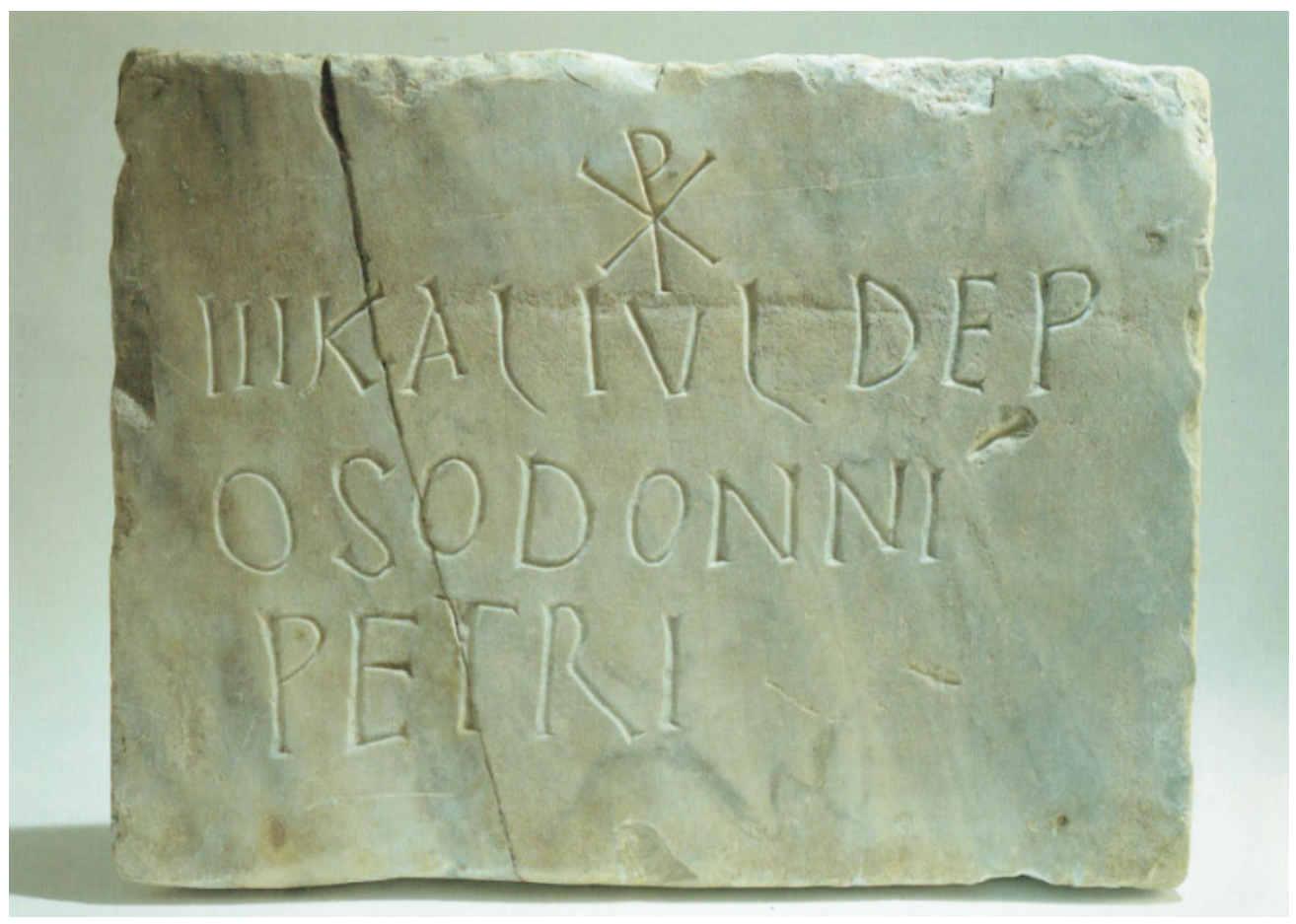

Figure 5. Sepulchral inscription of Peter, half 4th century. Source: [39].

The epigraph is dated to half of the 4th century. It is made of white marble, broken in two fragments, of total size $28 \times 37.5 \times 2.5 \mathrm{~cm}$. The height of the letters ranges from 3 to $4.5 \mathrm{~cm}$ [39] (p. 234). Therefore, just a single letter of the epigraph is bigger that the entire graffiti found near the trophy of Gaius, recalled in the Introduction. If that simple graffiti has been considered as the indirect proof of Peter's burial in St. Peter's Basilica on the Vatican Hill, then it cannot be excluded that the plaque of Figure 5 can be a proof that St. Peter, maybe for a certain period, was buried in the catacomb ad Duos Lauros.

The epigraph was found in 1912 in a cubicle of the region known as "delle agapi" (of agapes), in the South-West area [39] (p. 234), [40] (p. 76). The Christological monogram (first line) of the time of Constantine precedes the following funerary text: "III kal(endas) Jul(ias) dep/oso donni/Petri", that is "On June 29, deposition of the lord Peter" [39] (p. 234). The date, written in the second line, as it was usual in the Western world (at least till the 6th century), follows the Roman calendar and shows two abbreviations of current use.

Diehl, an expert of ancient Christian inscriptions [41], suggested that the epigraph was a memory of the dies natalis (i.e., the martyrdom) of Peter the Apostle [39] (p. 234) [41] (note 951), but his thesis was opposed by Ferrua [42], because there was no explanation for why the memory was in these catacombs. 
We can notice the corrupted expression deposo for depositio (lines 2-3) and donni for domini (line 3), a title attributed, for their respect, to saints and martyrs [39] (p. 234).

Shortly after Diehl's comments, another scholar, Marucchi-a major authority of Christian archeology-writes [43] (pp. 59-60) that the epigraph can be explained in two ways: (a) It could indicate the deposition on 29 June of the body of a Christian named Donnus Petrus, because Donnus could be also a name; (b) the rough writer, who carved deposo instead of depositio, would have wrongly written Donni, instead of Domni, because there are other known examples of this error; and in this case-he notes-Domnus, being the title given to the saints, it would seem natural to conclude that the Depositio Domni Petri indicated the feast of the apostle Peter.

Of the two hypotheses, Marucchi prefers the second one. Indeed, it was natural that the text depositio Domni Petri indicated the feast of St. Peter, on 29 June, as reported in the Depositio Martyrum till the 4th century. He also comments that the names Donnus or Domnus have not been found in cemeterial inscriptions. Moreover, he recalls and concludes that the title Domnus was given, per antonomasia, to St. Peter, thus becoming his solemn and characteristic title, as was also observed by another archeologist, De Rossi [44].

In fact, De Rossi [44] (p. 107) clarifies that in the Constantinian period, the title domnus was given only to bishops. It is not a case, therefore, that in the epigraph found in Megroun, placed on the culmination of an altar arch, the title is given only to Peter, not to Paul, even if they are both mentioned: "MEMORIA DOMNI PETRI ET PAVLI". At the time of his paper, the epigraph of Figure 5 had not yet been found.

Marucchi has also tried to explain the unexpected presence of the epigraph of Figure 5 in the catacombs of Sts. Marcellinus and Peter, by saying that originally the text was votive and that it continued in a smaller epigraph-never found-with the name of the dead person, who had died on the same day of St. Peter's martyrdom, i.e., 29 June [43] (p. 61), an evident ad hoc explanation far from being convincing [39] (p. 234).

The presence of Peter's remains in the catacombs of Sts. Marcellinus and Peter, therefore, would directly and simply explain why Constantine built the complex basilica and mausoleum in that area. Moreover, it has to be noted that Marcellinus and Peter, martyrs of the beginning of the 4th century, are ignored in the Depositio Martyrum contained in the Roman Calendar of the year 354 [35] (p. 133). This absence is very important because the basilica, supposedly dedicated to them, had been already erected in the years 320-325 [18] (pp. 45-46) [22] (p. 44) [23] (p. 64) [27] (p. 64) [36] (p. 130, 133). The passio of the two martyrs, written very likely at the beginning of the 6th century [36], (p. 134), tells that the martyrdom took place near Via Cornelia, in the opposite site of Rome, and their bodies, hurriedly buried in the same area, were moved to the cemetery ad Duos Lauros only later, by a lady named Lucilla, in absolute, as Giordani observes, the furthest cemetery from Via Cornelia [36] (pp. 139-140). In other words, the catacombs of Via Labicana in ancient time were not dedicated to them [36] (p. 140). To support this conclusion, Giordani mentions another archeologist, Guyon [28] who, with Deichmann and Tschira [27], has most studied these catacombs, and reached the same conclusions: In origin, these catacombs were not dedicated to the priest Marcellinus and the exorcist Peter, martyrs of the 4 th century. In fact, as we have noted, in the oldest copy of the Liber Pontificalis, 7th century, it is explicitly said that the basilica was dedicated to St. Peter the Apostle (Beato Petro), martyred with Marcellinus.

Moreover, Marucchi [38] (p. 500), [34] (p. 160) observes that, according to Liber Pontificalis, Pope Adrian I (VIII century) built (or re-built, the Latin word used is noviter which means "again", or also "recently") the stairway that goes down to the crypt of Sts. Marcellinus and Peter, at the time evidently not accessible from the basilica. The stairway was built inside a pre-existent gallery. The stairway and the crypt are indicated in the upper right side of Figure 3. Marucchi observes that it is difficult to accept the fact that the crypt could be accessed only under the papacy of Adrian I [34] (p. 160). However, if we admit that the Basilica was dedicated to the Blessed Peter (Beato Petro), the apostle, "cum Marcellino", i.e., martyred together Marcellinus in the I century, then it is possible that before the 8th century, there was no 
stairway at all. The writer of Liber Pontificalis, not knowing how to justify this fact (no stairway going to the crypt of the eponymous saints), might have understood that Adrian I restored a stairway previously existent, but deliberately obstructed, to conceal some important remains during the barbarian invasion of Rome. This may be the doubt expressed by Marucchi [34] (p. 160).

Moreover, many crypts or burial sepultures, have not yet been found in the catacombs of Sts. Marcellinus and Peter. Therefore, under the hypothesis that the apostle Peter was buried in the catacomb ad Duos Lauros, it is obvious to wonder where his crypt (and maybe even his remains) may be located within this cemeterial area. Indeed, the conjecture that Peter's remains, at least for a period if not forever, were buried in these catacombs can also be supported by other memories dedicated to him, found in the cemetery ad Duos Lauros.

The bodies of Marcellinus the priest and Peter the exorcist remained in the crypt until 826, under the papacy of Gregory IV, and were finally moved to Mainz (Germany) [33] (pp. 262-263). The remains of the Quattro Santi Coronati were moved by Pope Leo IV to their church of Celio, Rome. Later, the cemetery of Via Labicana was abandoned until it was re-discovered by Bosio, in the 17th century, who thought he had found the crypt of the two martyrs to whom the cemetery was dedicated [35]. After another period of oblivion, in 1852 it was the turn of De Rossi to explore these catacombs, and only in 1897 the PCAS started an excavation campaign [33] (p. 263).

The excavation was complicated by the fact that in the planimetry of underground Rome according to Bosio (1632), map edited by Berti and Contini [35], some cubicles were indicated as accessible, but they were not so in 1900 [45]. In fact, Wilpert, who just in those same years was excavating some cubicles already visited by Bosio but were later lost, clarified that when the paintings of a room had been copied by Bosio's drawers, that room was filled again with dirt, so that already Berti and Contini, who after Bosio's death drew the map, had to re-open their way [46]. In particular, of 14 cubicles published in Bosio's Roma Sotterranea [35], 6 of them were completely ignored till Wilpert's time.

It is interesting to read the comment by Giuliani, who has recently worked in a restoration project of the frescoes of the catacombs of Sts. Marcellinus and Peter [45] (p. 86): "From what we have observed, at the time of A. Bosio to allow him to reconnoiter the area and, above all, to allow his copyists to reproduce the paintings of underground Rome, the dirt obstructing the rooms was moved, in cursory and provisional way, from one place to another and later moved back, so that the drawers of Bosio's map had to re-dig some rooms already visited by him. This explains, at least partially, the extremely precarious state of the room under restoration".

After recalling that many cubicles have not yet been explored or, if explored, later obstructed again, especially in the second level of the catacombs, we should also recall that the epigraph on Peter's depositio was found out of place [43] (p. 60), in a cubicle of the area "of the agapes", corresponding to the quadrant B7-area colored in blue-of the map shown in Figure 6. The numbers given to the cubicles with frescoes was done before the 1971 edition of the book by Nestori, later published in an expanded edition [47]. Since 1971, by convention, Nestori's numeration has been followed, also in the map by Deckers [31], shown in Figure 6. 


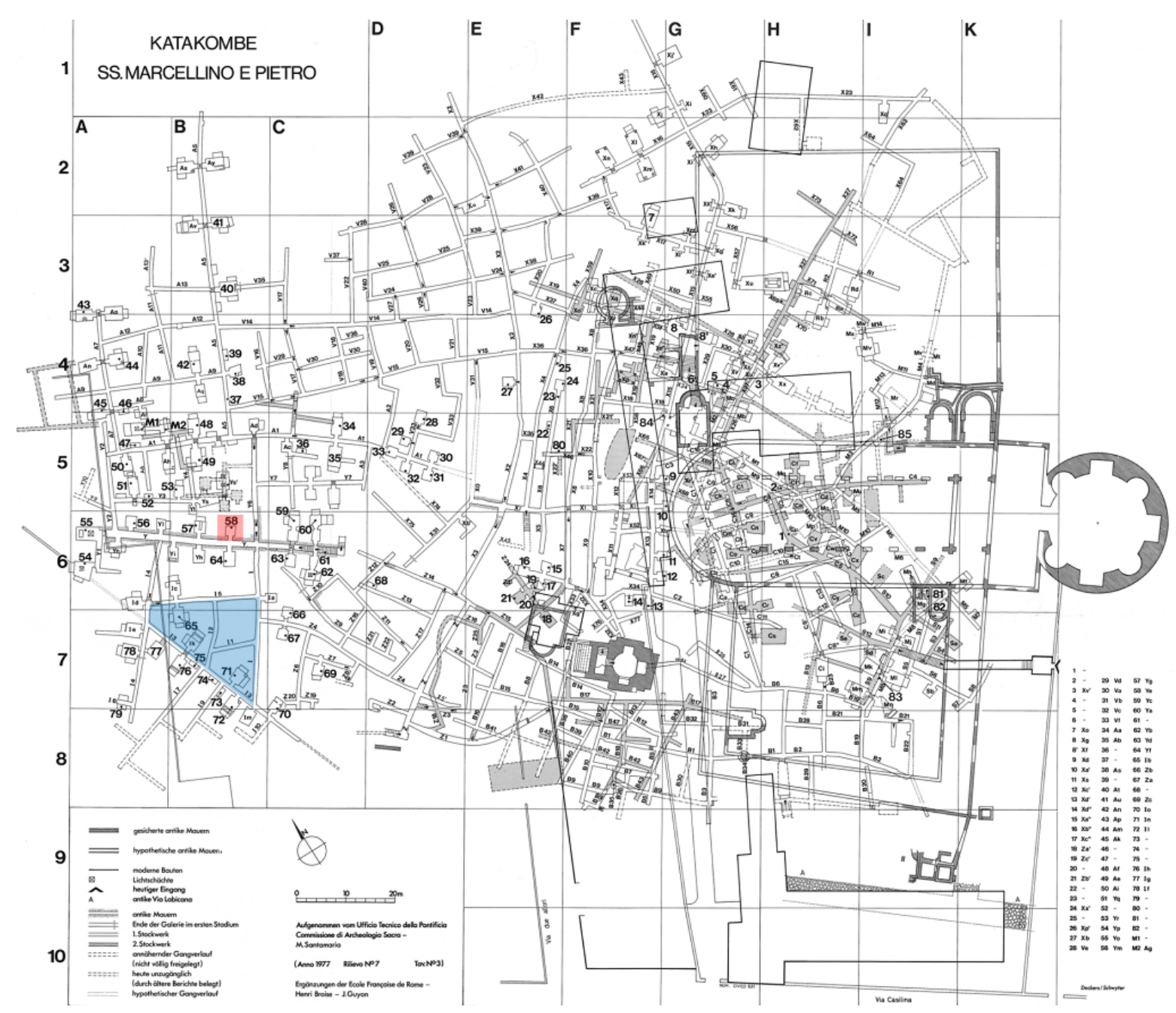

Figure 6. Planimetry of the catacombs of the Sts. Marcellinus and Peter, from PCAS's archive. The region "delle Agapi" ("of the agapes") is evidenced in blue. The red area is the cubicle number 58, where St. Peter's fresco was found. Source of the original planimetry: [31].

Of the many cubicles reported in Figure 6, the most important seems to be cubicle no. 58-the red area in Figure 6, located just a little North of the region where the epigraph was found. In this cubicle there is a fresco depicting St. Peter holding a scroll. Figure 7 (panels $a$ and $b$ ) shows a watercolor of this fresco, published by J. Wilpert [48], which he attributes to the "the Prince of the Apostles" and to the second half the 3rd century. The comparison with the black and white photograph of this fresco ${ }^{1}$ shows the accuracy and precision of the artist, C. Tabanelli, who copied it. On this artist, Wilpert observes [46] (volume 1, p. 180) that Tabanelli, who had worked before with De Rossi, had an extraordinary talent for copying frescos. 


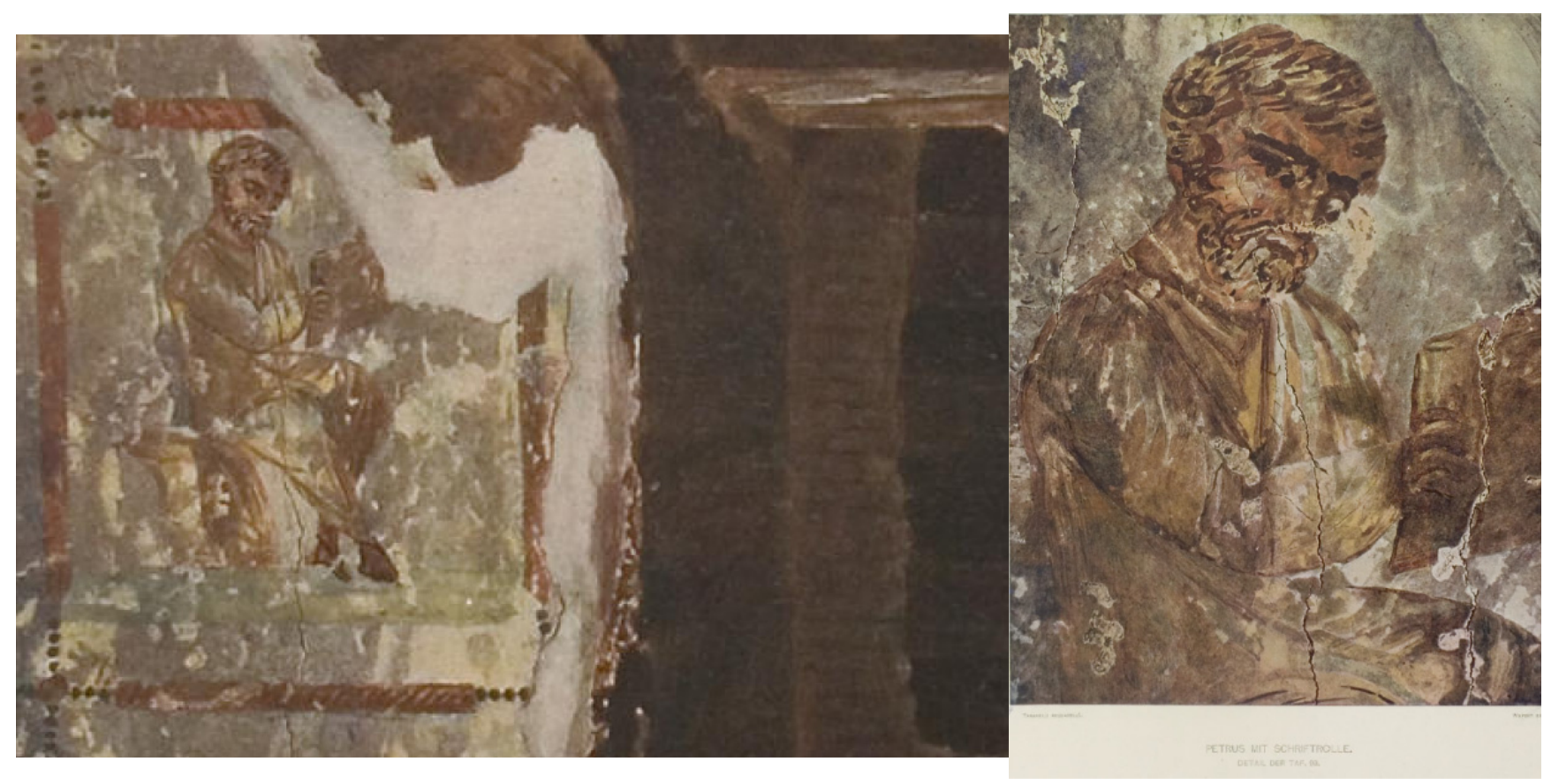

(a)

(b)

Figure 7. (a) Detail of Figure no. 93 published in [48]. It shows a watercolor of St. Peter's fresco found in the cubicle no. 58 of the catacombs of the Sts. Marcellinus and Peter. (b) Detail with the legend "Peter with scroll" (Petrus Mit Schriftrolle).

In conclusion, the North-West region close to cubicle no. 58 shows significant traces of the presence of St. Peter's memories, therefore, in the next section, we search the precise area where his remains might have been buried for a period, or, maybe, might still be.

\section{The Area Where St. Peter's Remains Might Have Been Buried}

Following the discussion of the previous sections, it is obvious to search the alleged crypt of St. Peter near the cubicle no. 58. To find the area of the site where St. Peter's remains were likely buried and, perhaps, might still be, we explore some interesting geometrical relationships, worthy of note, in the planimetry of the area, first in general terms, secondly with some mathematical calculations, reported in the Appendix A. Both approaches lead to a very restricted area near the cubicle 58 .

\subsection{Geometrical Relationships Deducible from the Planimetry}

Besides the different orientation of the narthex and the basilica already evidenced in Figure 3, another striking fact is that the tangent line to the mausoleum, conducted along the short side of the narthex, crosses exactly the cubicle 58, as shown in Figure 8 . The planimetry is now rotated $90^{\circ}$ counterclockwise for later allowing the comparison with a map by Bosio [35]; the angle, termed $\alpha$, between the vertical dashed line (the North direction is rotated $32^{\circ}$ clockwise from this line) and the line parallel to the short side of the narthex (red continuous line) is about $4^{\circ}$. 


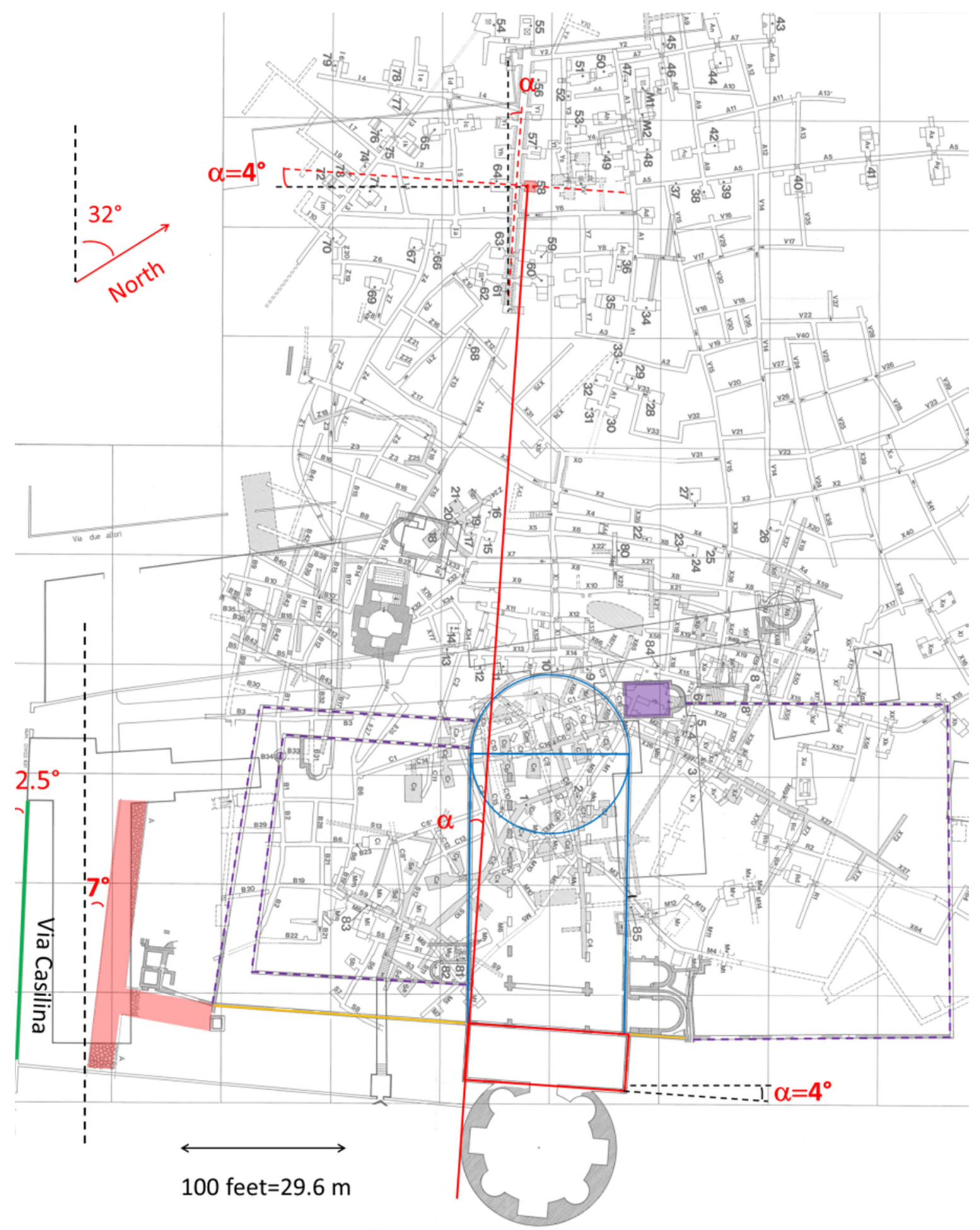

Figure 8. Planimetry (detail) of the catacombs of the Sts. Marcellinus and Peter, from the Archivio della Pontificia Commissione di Archeologia Sacra (PCAS) [31], rotated $90^{\circ}$ counterclockwise. The cubicle no. 58 with St. Peter's fresco is evidenced in red. The line tangent to the Mausoleum (red line) is parallel to the short side of the narthex and it intersects the cubicle 58. Both cubicle 58 and its access gallery, named Galleria dei 4 Coronati (Gallery of the Four Crowned), dashed red line almost vertical, are parallel to the short side of the narthex.

Of course, the crossing of cubicle 58 might occur just for chance, but we can notice that the only important gallery with this same direction, found in the whole catacombs area, is the Gallery of the Four Crowned (Quattro Coronati, dashed red line), Figure 8. Now the 
cubicle 58 has its entrance at $90^{\circ}$ with this gallery, therefore this cubicle has its entrance side parallel to the short sides of the narthex.

Now, a surprising conjecture can be proposed. The asymmetry of the basilica, compared to the narthex, and its dimensions-as the dimensions of the mausoleum-were all planned to encode the information leading to the crypt of St. Peter Apostle, the real eponymous of the catacombs of the Sts. Marcellinus and Peter.

As a verification of this hypothesis, let us notice that the outer and inner circles of the mausoleum (today, very often referred to as Tor Pignattara) have not standard size, if compared to other mausolea and circular buildings built by the Romans [32] (p. 118). The diameter of the outer circumference measures $27.74 \mathrm{~m}$, i.e., 93.72 Roman feet (1 Roman foot is equal to $0.296 \mathrm{~m}$ ); the diameter of the inner circumference measures $20.18 \mathrm{~m}$, or 68.18 feet [32] (p. 145). These lengths are unusual because the standard choice in imperial Roman buildings was to use multiples of 10,12, or 16 feet [32] (p. 118).

Moreover, it is possible to identify in Figure 3 an inner semi-circle in the apse of the basilica, indicated with the dashed blue line in Figure 9, besides the outer (continuous blue line) semi-circle of the apse. In Figure 9, we have traced the full circles to show that the outer circumference of the apse is about equal to the outer circumference of the mausoleum.

At this point, in Figure 9 we can notice another relevant "coincidence": The line tangent to the two inner circles (mausoleum, apse, green line) is parallel to the line tangent to the outer circle of the mausoleum and short side of the narthex (red line), evidently not by chance. Both are inclined by the angle $\alpha=4^{\circ}$. In other words, it seems that the mausoleum and basilica complex was planned and built following a single plan. Our conjecture can be verified mathematically.

As shown in the Appendix A, mathematical calculations confirm that the inner semicircle of the apse was designed in relation with the inner circle of the mausoleum because the two lines $r_{1}$ and $r_{2}$ are parallel (see Figure 9).

Figure 10 shows the enlarged Eastern part of the planimetry. Line $r_{3}$, tangent to the outer circle of the mausoleum and to the inner semi-circle of the apse, North side, seems to be specular of line $r_{2}$ with reference to $y$-axis, with an angle $-\alpha$. This specularity can be assessed with Equations (A1)-(A3) of the Appendix A applied to this case: We get the angle $\alpha=-3.9^{\circ} \pm 0.1^{\circ}$. Therefore, the values of the two angles confirm the mirror symmetry (specularity) of lines $r_{2}$ and $r_{3}$ with respect to the reference $y$ - axis. Notice that line $r_{2}$ is tangent to the two inner circles of the mausoleum and apse, while line $r_{3}$ is tangent to the outer circle of the mausoleum and to the inner circle of the apse, a proof, in our opinion, of the unitariness of the design and construction of the complex. Now, the ancient wall of the cemetery of the Equites Singulares Augusti may have affected the direction of the short side of the narthex, but the long side of the Basilica could have maintained the same direction of the narthex and, thus, obtaining the ordered beauty of the classic Roman basilica of practically the same total surface $(-5 \%$, see Section 3$)$. However, this was not the choice of the planners. The long side of the basilica was tilted counterclockwise exactly by $4^{\circ}$. Why? 


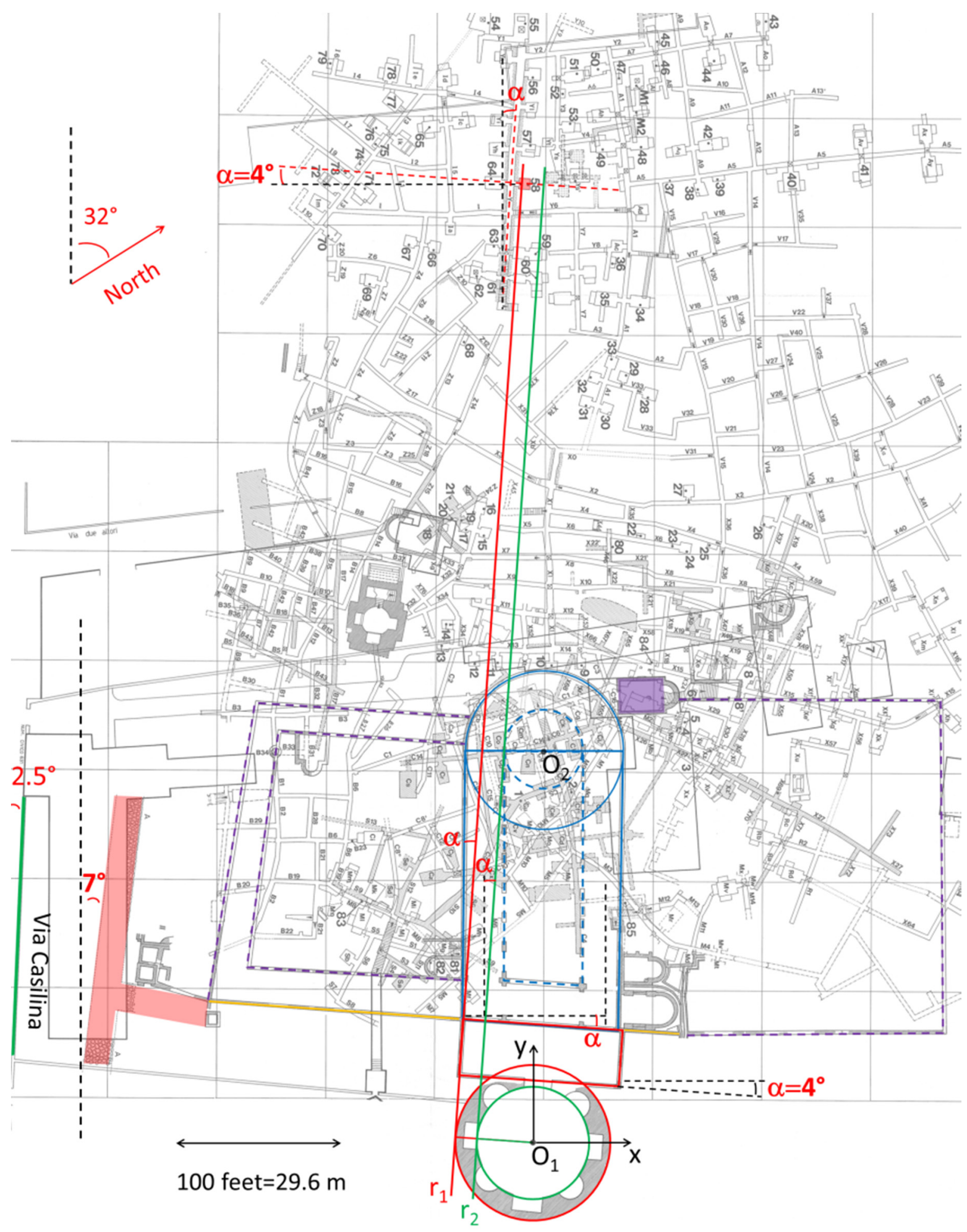

Figure 9. Planimetry (detail) of the catacombs of the Sts. Marcellinus and Peter, from the Archivio of PCAS [31], rotated 90 counterclockwise. The cubicle 58 with St. Peter's fresco is evidenced in red. The red line tangent to the outer circle of the mausoleum (in red) is directed (parallel) as the short side of the narthex. The green line is tangent to the inner circle of the mausoleum (green) and to the inner semi-circle of the apse (dashed blue line). The two tangent lines are parallel. 


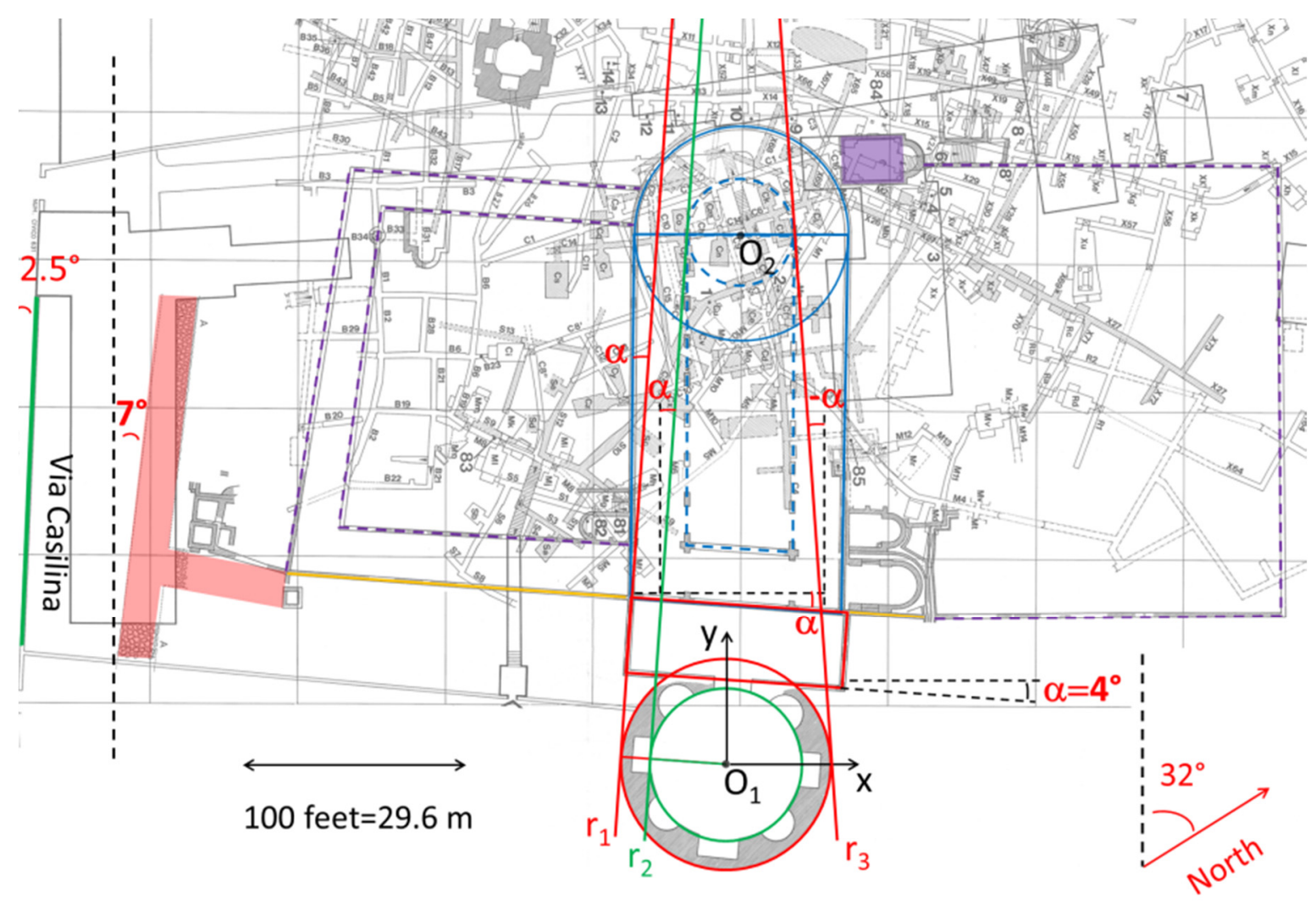

Figure 10. Detail of the East part of the catacombs of the Sts. Marcellinus and Peter. Line $r_{3}$, tangent to the outer circle of the mausoleum and to the inner semi-circle of the apse, North side, is specular to line $r_{1}$ with respect to the $y$ - axis (mirror symmetry).

In Figure 11, we have drawn line $r_{4}$, specular of line $r_{2}$, parallel to line $r_{3}$ and tangent to the inner circle of the mausoleum, North side. In the Appendix A, we show that lines $r_{1}$ and $r_{4}$ intersect at the cubicle 58 (see point $P_{1}$ in Figure 12), and lines $r_{2}$ and $r_{3}$ intersect at point $P_{2}$.

Indeed, point $P_{1}$ practically falls inside the cubicle 58 , whose sides are $3 \mathrm{~m}$, or falls very close to it, within the errors of calculations of $\pm 4.4 \mathrm{~m}$, on the $y$ coordinate, which are large because of the small values of $\alpha$. If we consider that the distance between the center of the cubicle 58 and the origin of the Cartesian coordinates (center of the Mausoleum) is about $173 \mathrm{~m}$, this is a striking result.

The coordinates of point $P_{2}$, intersection of the lines $r_{2}$ and $r_{3}$, are calculated similarly (see the Appendix A). $P_{2}$ is a little outside the cubicle 58 , moved to the right by the difference of the radii of the mausoleum $R_{E}-R_{I}=3.78 \mathrm{~m}$. Once more, the radii of the circles of the mausoleum and the inner circle of the apse play a fundamental role. The details of the area of the intersections of the four straight lines are shown in Figure 12. 


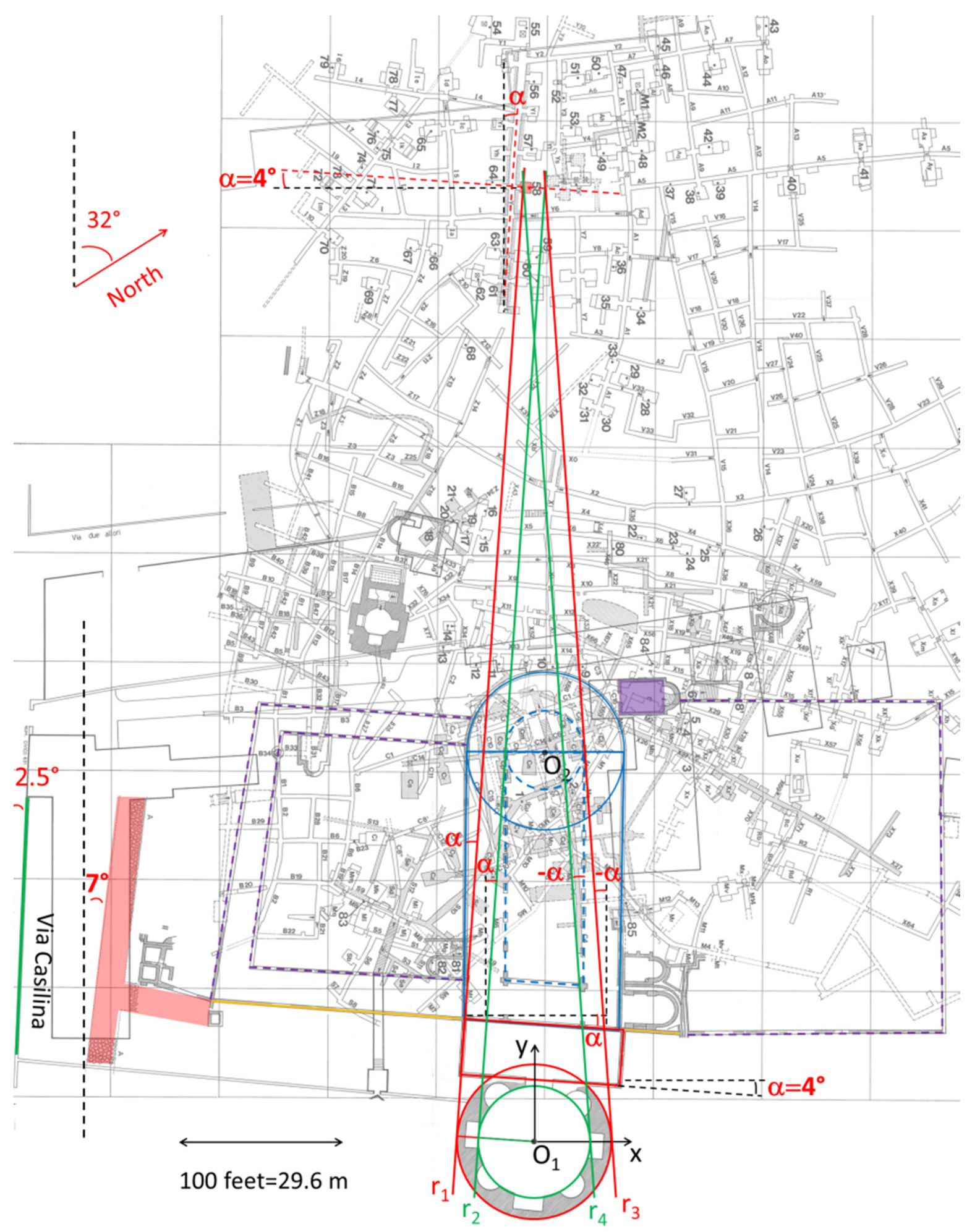

Figure 11. Detail of the East part of the catacombs of the Sts. Marcellinus and Peter. The cubicle 58 with St. Peter's fresco is evidenced in red. Line $r_{4}$, tangent to the inner circle of the mausoleum, North side, is specular to line $r_{2}$ with respect to the $y$ - axis (mirror symmetry). 


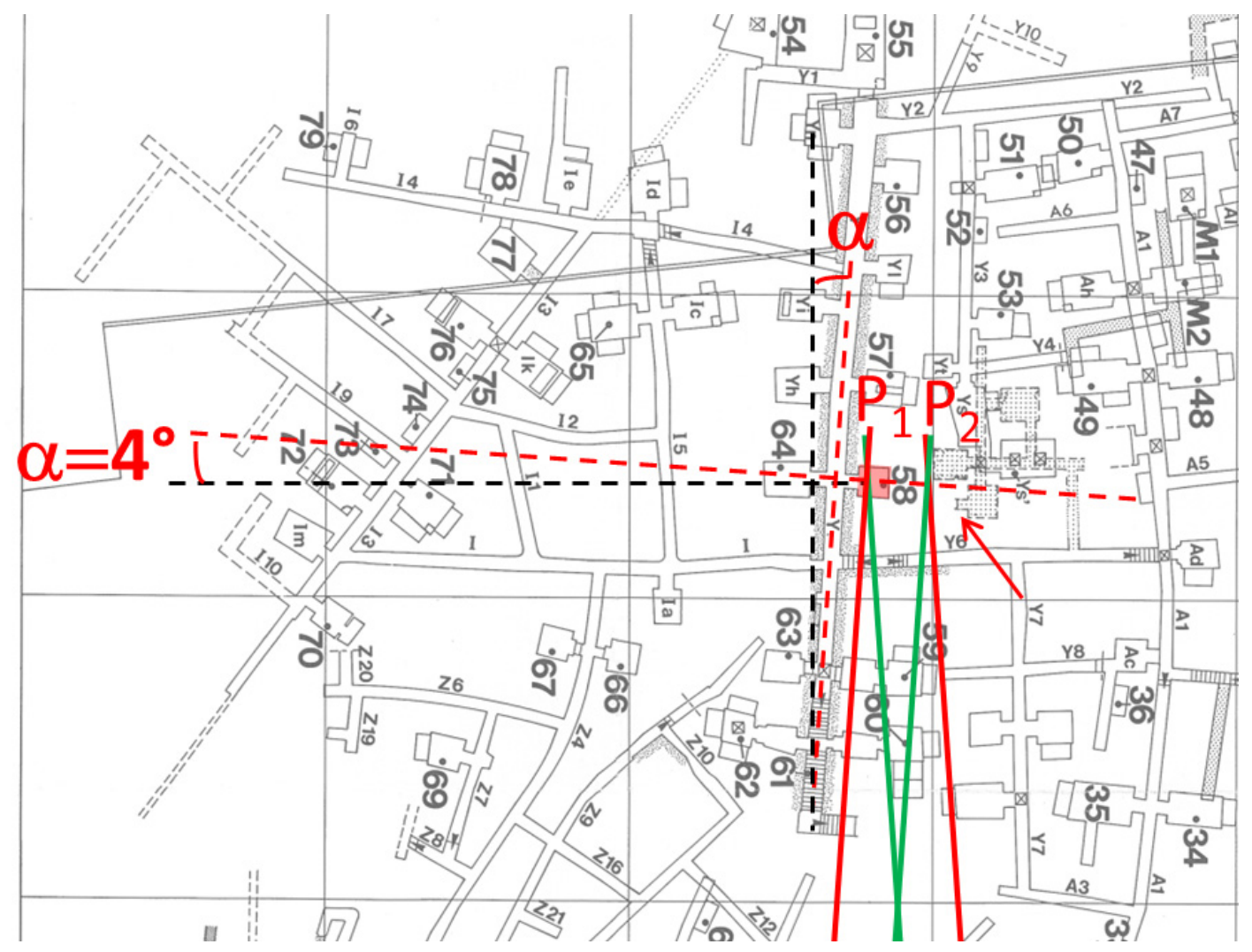

Figure 12. Detail of the area of the cubicle 58. $P_{1}=\left(x_{C}, y_{C}\right)$ and $P_{2}=\left(x_{T}, y_{T}\right)$, calculated in the Appendix A, are the intersection points of the lines drawn in Figure 11. The red arrow indicates an interrupted gallery, which is at the second level of the catacombs, not yet completely explored. This gallery falls very close to the cubicle 58 and the Gallery of the Four Crowned, but it should indicate a site at a lower level.

\subsection{Many Unexplored Cubicles and Galleries}

According to the results of the previous sections, the intersection $P_{2}$ between lines $r_{2}$ and $r_{3}$ falls within an area apparently without cubicles (Figure 12). However, we must remember that in that area, the catacombs are deployed in two levels, with the lowest (second) level drawn with gray dots in Figure 12. As indicated by the red arrow, in the second level there are galleries not completely explored by Bosio [35], because how they appear in his map, and still as unexplored galleries are also reported in the maps of the PCAS archive [31] that we have used to draw Figure 12. To better appreciate the details, Figure 13 shows Bosio's map [35] corresponding to the same region of that shown in Figure 12, with the same orientation of Figure 12. The dashed cubicles in his map are those located in the second level. It can be noted that in the area designed with number 28, tunnels are obstructed, as indicated by the red arrow in Figure 12. Bosio did not explore this area very likely because of obstructions or because it was unsafe. In fact, the archeologists of the beginning of the 20th century, who were exploring the first level in the area of the Galleria dei Quattro Coronati, did know that the lowest level was unsafe. The explorations proceeded with caution only after strengthening the area with large pillars, because of deep caves in the second level [40] (p. 74). 


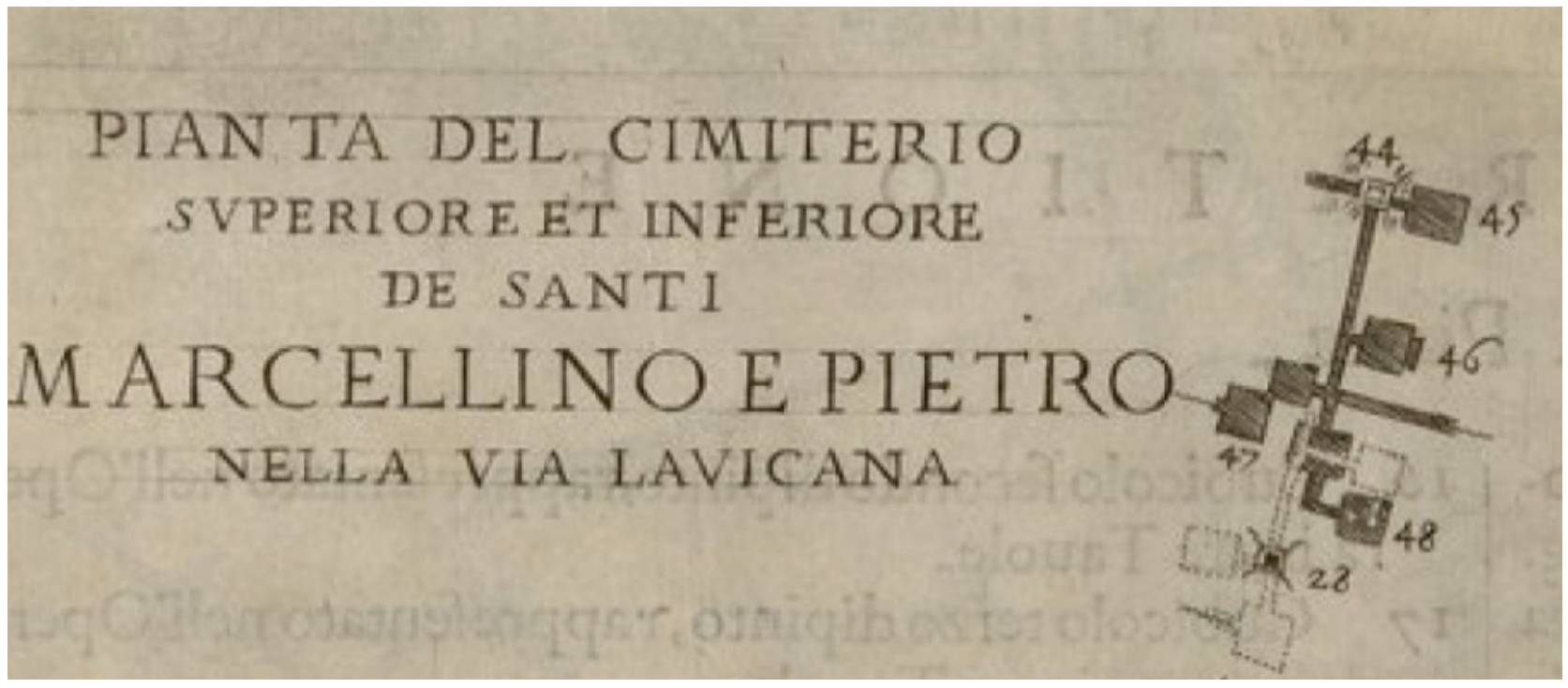

Figure 13. Detail of the planimetry drawn by A. Bosio [35] of the same area and orientation of Figure 12, upper right side. Bosio's cubicle no. 47 corresponds to Nestori's cubicle no. 57 of Figure 12 [47] (p. 69). This cubicle is encountered just after cubicle 58 along the direction of the $y$ - axis.

Moreover, in the most recent maps of the PCAS archive, the second level of the catacombs, near the cubicle 58, is not even drawn, as it can be noticed in Figure 1 of a very recent paper concerning the catacombs of Sts. Marcellinus and Peter [49] (p. 1024), Indeed, in this published map [49], below cubicle 58 - which is visitable and presents an ambient connected to the left, marked as an arcosolium (an arched niche), not reported in the map published in [31] (Figure 12) 40 years earlier-no second level is indicated.

Now, if our conjecture is plausible, the question that arises is how the Roman architects and engineers of the time (beginning of 4th century) could be so precise. They had to plan the length of the radii of the mausoleum and apse in such a precise relation to make lines $r_{1}$ and $r_{4}$ intersect in $P_{1}$ and lines $r_{2}$ and $r_{3}$ intersect in $P_{2}$, therefore referring the angle $\alpha=4^{\circ}$ to an underground site, e.g., the cubicle 58 , obviously not visible.

It is well known that Roman engineers were able to build very long aqueducts with very small slopes [50], down to $8 \mathrm{~cm}$ per $1 \mathrm{~km}$, i.e., inclined of an average angle $\beta=\arctan (0.08 / 1000) \approx 0.00008 \mathrm{rad}=0.0046^{\circ}$. If they were able to manage such a small angle, although with the help of gravity [51], they might as well managed angles 3 orders of magnitude larger.

As for the "visibility" of cubicle 58 or the interrupted galleries close to it, Bosio himself seems to provide the solution devised by the Roman architects and engineers working in the cemeterial area [35]. Notice, in fact, that in correspondence of number 28, see Figure 13, there is a black square dot with an " $\times$ " on it. Bosio writes that he had found "openings, or narrow openings, which coincided on the surface [with galleries or cubicles underground], but now filled" [35]. These narrow openings were usually built for providing air circulation and light, down to many levels (ventilation and light shafts, lucernaria and luminaria), and could also be used, of course, to sign, with a post, the presence of an underground reference cubicle. Now, what the Roman architects had to do was just to pull few ropes of about 180 $\mathrm{m}$ long to draw all the relevant lines of the complex, with a very small error.

Moreover, Bosio describes cubicle no. 48 of his map which, curiously, does not correspond to any cubicle of the catalogue prepared by Nestori [47]: “ . . cubicle that has, in its vault, a narrow opening open from which it is possible to climb to other cubicles and cemeterial roads of the superior level, indicated with dots" [34]. In other words, the cubicle explored by Bosio was in the second level and it allowed to pass from the second level to the first level not by a stairway but by a hole in the ceiling, just near $P_{2}$, that is, near the tunnel interrupted indicated by the red arrow in Figure 12. As noticed, his cubicle 48 
has no correspondence in the modern maps [47], thus indicating either a possible error by Bosio or a cubicle not yet found by more recent explorations.

Now, we know for certain that in the second level there should be the crypt of the martyr Gorgonius, but this crypt has not yet been found because the second level has not been fully explored [52] (p. 238). The Salzburg Itinerary [33] (p. 257) indicates that the crypt of Gorgonius is encountered just after that of Sts. Peter and Marcellinus, in the same (second) level: "then you will enter an underground where the saint martyrs rest, Petrus the priest and Marcellinus martyr. Then at the same underground you will find martyr Gorgonius". If the Itinerary were mentioning the crypt of Sts. Marcellinus and Peter of the 4th century, attached to the basilica (violet area in Figure 11), then the crypt of Gorgonius should have been found long ago because this area has been completely explored. On the other hand, quite different is the situation for the second level in the area to the North of the Galleria dei Quattro Coronati, in the upright side of Figure 12.

The name of Gorgonius is also listed in Depositio Martyrum, and it is believed that he was one of the first martyrs to be moved to the cemeterial area ad Duos Lauros, very likely after the persecutions of Valerianus [36] (pp. 128,131). Moreover, the remains of the apostles Peter and Paul were buried ad catacumbas, very likely during the persecutions of Valerianus, because of the year 258 of the consulate by Tusco and Basso, mentioned in Depositio Martyrum [12]. Therefore, it is possible that also Peter the Apostle and Marcellinus the martyr were moved to the oldest nucleus of the catacombs, and in the lowest level, hidden in anonymity to avoid profanation.

According to our reconstruction and conjecture concerning the design of the mausoleum and basilica complex in the catacombs of Sts. Marcellinus and Peter, the Roman Christians, and also Constantine, still knew where St. Peter's remains were buried, i.e., in the second level near the cubicle 58 of the first level.

It must be recalled that in the 5th or 6th century, all cubicles facing the Galleria dei Quattro Coronati were walled up [52] (p. 238), including cubicle 58 with the apostle Peter's fresco. Part of the wall, with a hole to enter the cubicle, is also shown in the watercolor reported in Figure 7a (right part of Figure 7). Testini suggests that the walls were built to reinforce the tunnel and thus allow a larger number of visiting pilgrims to the cubicle of the Quattro Coronati [52] (p. 238), cubicle no. 54 in Figure 12. However, it is curious that to favor the influx of many pilgrims, someone restricted the tunnel by building a side wall. We think that the cubicles were walled up to hide any possible reference to St. Peter the Apostle, including the watercolor, in the years of destruction and profanation due to barbarian invasions.

\subsection{Precision of the Complex Design: Fine Tuning}

In the Appendix A, we have shown that lines $r_{1}$ and $r_{4}$ intersect at cubicle no. 58 (point $P_{1}$ in Figure 12). We explore now how the coordinates of this intersection depend of the input data, namely the diameters of the mausoleum and apse. As recalled, the Roman architects designed lengths preferably using multiples of 10 Roman feet [32] (p. 118). Let us adopt the closest multiples of 10 for the diameters, see Table 1 . We notice that the largest variation is about $1 \mathrm{~m}$ for diameters, $0.5 \mathrm{~m}$ for radii, equivalent to the thickness of a wall. It is sufficient to use just these small variations to appreciate the extreme sensitivity of the intersection point coordinates. 
Table 1. Variation of the diameters of the mausoleum and apse. The integer multiple of 10 (column 3) is the closest integer value to the actual diameter (column 2). One Roman foot equals $0.296 \mathrm{~m}$ [32] (p. 118).

\begin{tabular}{cccc}
\hline $\begin{array}{c}\text { Architectonic } \\
\text { Element }\end{array}$ & $\begin{array}{c}\text { Diameter } \\
\text { (Roman Feet) }\end{array}$ & $\begin{array}{c}\text { Closest Integer } \\
\text { Multiple } \\
\text { (Roman Feet) }\end{array}$ & $\begin{array}{c}\text { Difference } \\
\text { (Meters) }\end{array}$ \\
\hline $\begin{array}{c}\text { Mausoleum outer } \\
\text { circle }\left(2 \times R_{E}\right)\end{array}$ & 93.72 & 90 & -1.10 \\
\hline $\begin{array}{c}\text { Mausoleum inner } \\
\text { circle }\left(2 \times R_{I}\right)\end{array}$ & 68.18 & 70 & +0.54 \\
\hline $\begin{array}{c}\text { Inner apse semi-circle } \\
\left(2 \times R_{B}\right)\end{array}$ & 48.10 & 50 & +0.56 \\
\hline
\end{tabular}

Figure 14 shows the intersections obtained with the diameters listed in Table 1. We notice that $\alpha=4^{\circ}$, because of constraint due to the wall of the cemetery of the Equites Singulares Augusti, but the specular angle is $\alpha^{\prime}=3.2^{\circ}$. Now lines $r_{1}$ and $r_{4}$ and lines $r_{2}$ and $r_{3}$ intersect at new points (red small circles), at about $14.3 \mathrm{~m}$ from $P_{1}$ and $P_{2}$. Therefore, differences in diameters of only 2 or 3 feet (about $1 \%$ ) give differences of $14 \mathrm{~m}$, about $8 \%$ of the distance between the origin $O_{1}$ and cubicle 58 . No intersection falls on cubicle 58. In conclusion, there must have been a very "fine tuning" of the lengths of the diameters to end up in $P_{1}$ (cubicle 58) and in $P_{2}$. Our hypothesis is that this fine tuning was done on purpose.

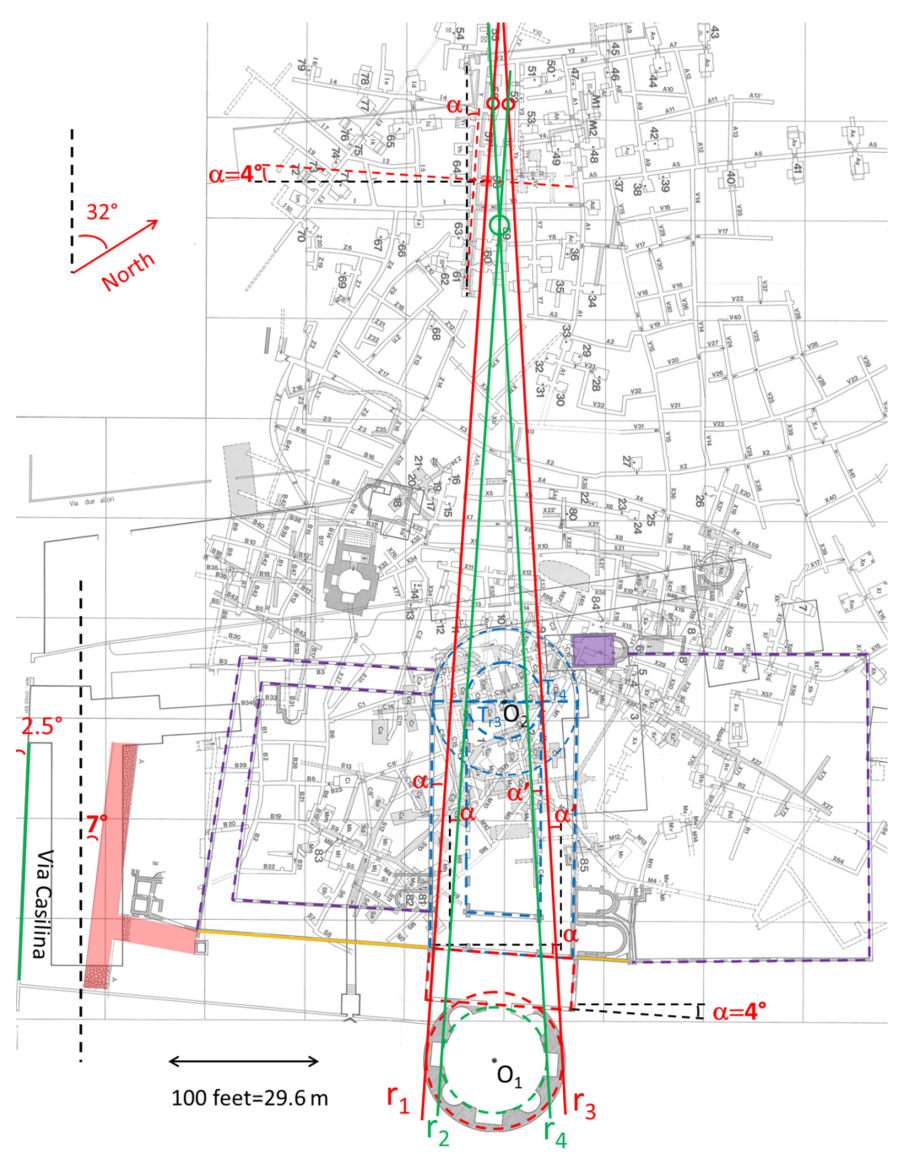

Figure 14. Detail of the catacombs of the Sts. Marcellinus and Peter. The cubicle 58 with St. Peter's fresco is evidenced in red. The diameters of the mausoleum and apse have been varied according to Table 1. Lines $r_{1}$ and $r_{3}$ are no longer specular with respect to the $y$ - axis, because $\alpha^{\prime}=-3.2^{\circ}$, not $4^{\circ}$, and none of the intersections of the four lines (red and green circles) fall on cubicle 58. 


\section{Conclusions and Future Work}

In light of the many elements analyzed, and especially those outlined in the last section, we conjecture that St. Peter's crypt, very likely still containing his remains, could be located at the second level of the catacombs of Sts. Marcellinus and Peter-in the suburbs of Rome known as Tor Pignattara - very close to point $P_{2}$ indicated in Figure 12. Our conjecture is very well supported by several historical and archeological elements recalled in detail, but also by our striking discovery concerning the unusual architectonic characteristics of the basilica and mausoleum, inexplicable in the ordered and mostly symmetrical architecture of the Roman world. Our mathematical analysis has shown that the basilica and mausoleum were part of a single architectonic plan, very likely designed for coding important data useful to locate Peter's burial site unambiguously.

It is very striking that Maria Valtorta, the Italian mystic consulted by the Vatican on where Peter's remains might have been buried - as we have mentioned in the Introductionin her writings [53,54] indicated the catacombs of Sts. Marcellinus and Peter, and even described, with many details, the crypt and St. Peter's body, mummified and holding a scroll in his hands, strikingly in agreement with the fresco discovered in cubicle 58 (point $P_{1}$ ).

The exploration of the second level of the catacombs deployed in the area very close to point $P_{2}$ could be of considerable importance, not only for verifying the solidity of our conjecture, but mainly for finding either St. Peter's remains or his crypt, a great achievement not only for archeologists, but also for all Christian Confessions, therefore confirming the ancient tradition of the Depositio Martyrum of the year 336, which describes the memory of the apostle ad catacumbas, just in the historical period in which the first St. Peter's Basilica was built.

Author Contributions: All authors have contributed to write the paper and discuss the results. All authors have read and agreed to the published version of the manuscript.

Funding: This research has received no founding.

Acknowledgments: The authors wish to thank Raffaella Giuliani of the PCAS for helping us in our research by providing a high resolution map of the Sts Marcellino and Peter's catacombs [31], used in our study.

Conflicts of Interest: The authors declare no conflict of interest.

\section{Appendix A. Mathematical Calculations}

Let us refer to a Cartesian orthogonal coordinates system, with the origin at the center of the mausoleum, point $O_{1}$ in Figure 9. The center of the semi-circles of the apse is at $O_{2}$ with coordinates in pixels $(22 ; 794)$, with the minimum precision of 1 pixel. The size of Figure 9, in pixels, is $1927 \times 2506$. The lengths of the diameters of the Mausoleum have been measured and reported in the literature with the precision of $1 \mathrm{~mm}$ [32] (p. 145). Indicated with $R_{E}=13.870 \pm 0.005 \mathrm{~m}$ the radius of the outer circle of the mausoleum-red circle in Figure 9-and with $R_{I}=10.090 \pm 0.005 \mathrm{~m}$ the radius of the inner circle of the Mausoleum - green circle in Figure 9-from the planimetry we get the length of the radii in pixels $R_{E}=156.0 \pm 0.5$ and $R_{I}=113.5 \pm 0.5$. The precision of the length to 0.5 pixel or to $0.005 \mathrm{~m}$ is due to dividing the diameter by 2 .

Now the equation of line $r_{2}$ in Figure 9, tangent to the circles of radii $R_{I}$ and $R_{B}$, can be calculated by imposing that the distance of the line from the origin $O_{1}(0,0)$ is $R_{I}$ and its distance from $\mathrm{O}_{2}$ is $R_{B}$. Let $y=m x+q$ be the equation of a line, and let $\mathrm{O}_{2}=\left(x_{02}, y_{02}\right)$. The unknown slope $m$ and the intercept $q$ of the line are obtained by solving the following two quadratic equations:

$$
\begin{gathered}
R_{I}^{2}=\frac{q^{2}}{m^{2}+1} \\
R_{B}^{2}=\frac{\left(m x_{02}+q-y_{02}\right)^{2}}{m^{2}+1}
\end{gathered}
$$


The radius of the semi-circle of the apse, dashed blue curve in Figure 9, not given in [32], can be accurately computed from Figure 9 (and Figure 3). The linear size of a pixel corresponds to $\Delta_{\text {Pix }}=\frac{13.87 \pm 0.005}{156.0 \pm 0.5}=0.089 \pm 0.0001 \mathrm{~m}$, i.e., $8.9 \mathrm{~cm} \pm 0.1 \mathrm{~mm}$. This error is so small that all distances and angles measured from this planimetry are very accurate. It follows that the radius of the inner semi-circle of the apse (dashed blue curve in Figure 9), is $R_{B}=80 \pm 1$, pixels, or $R_{B}=7.12 \pm 0.09 \mathrm{~m}$, calculated by considering the distance between $\mathrm{O}_{2}$ and half the depth of the wall $-70 \mathrm{~cm}$ (about 8 pixels)—of the inner semi-circle of the apse.

The particular solution of Equation (A1) applicable to our case-out of four-is that giving the leftmost tangent to the two circles, i.e.,:

$$
\begin{gathered}
m=\frac{-x_{02} y_{02}+\Delta}{\left(R_{I}-R_{B}\right)^{2}-x_{02}^{2}} \\
q=\frac{\left(R_{I}-R_{B}\right)^{2} y_{02}-x_{02} \Delta}{\left(R_{I}-R_{B}\right)^{2}-x_{02}^{2}} \times \frac{R_{I}}{R_{I}-R_{B}}
\end{gathered}
$$

with

$$
\Delta=\sqrt{\left(R_{I}-R_{B}\right)^{2} \times\left[x_{02}^{2}+y_{02}^{2}-\left(R_{I}-R_{B}\right)^{2}\right]}
$$

Inserting in Equations (A2) and (A3) the values of the diameters of the circles and the coordinates of $\mathrm{O}_{2}$ we get the parameters of line $r_{2}$ of Figure $9, m_{2}=14.29 \pm 0.40$ and $q_{2}=1625 \pm 39$ pixels. Now, because the parameter $m_{2}$ is connected to the angle $\alpha$ by the following relationship:

$$
m_{2}=\tan \left(90^{\circ}-\alpha\right)
$$

from Equation (A4) we get $\alpha=4.0^{\circ} \pm 0.1^{\circ}$. This angular value compares very well with the angle formed by the wall of the cemetery of the Equites Singulares Augusti (yellow line in Figure 9), given by $\alpha=4.2^{\circ} \pm 0.1^{\circ}$. Now, if we consider the accuracy with which they are calculated, the two angles coincide. In other words, the inner semi-circle of the apse was designed in relation with the inner circle of the mausoleum because, as now established, the two lines $r_{1}$ and $r_{2}$ are parallel.

Figure 10 shows the enlarged Eastern part of the planimetry. Line $r_{3}$, tangent to the outer circle of the mausoleum and to the inner semi-circle of the apse, North side, seems to be specular of line $r_{2}$ with reference to $y$ - axis, with an angle $-\alpha$. This specularity can be assessed with Equations (A1)-(A3) of the Appendix A applied to this case: We get the parameters of line $r_{3}$, namely $m_{3}=-14.66 \pm 0.42$ and $q_{3}=2292 \pm 59$ pixels, and from Equation (A4) we get the angle $\alpha=-3.9^{\circ} \pm 0.1^{\circ}$. Therefore, the values of the two angles confirm the mirror symmetry (specularity) of lines $r_{2}$ and $r_{3}$ with respect to the reference $y-$ axis.

In Figure 11, we have drawn line $r_{4}$, specular of line $r_{2}$, parallel to line $r_{3}$, and tangent to the inner circle of the mausoleum, North side. We show now that lines $r_{1}$ and $r_{4}$ intersect at cubicle 58 (see point $P_{1}$ in Figure 12), and lines $r_{2}$ and $r_{3}$ intersect at point $P_{2}$.

The coordinates $x_{C}$ and $y_{C}$ of the intersection point of lines $r_{1}$ and $r_{4}\left(P_{1}\right)$ are calculated from:

$$
\begin{gathered}
x_{C}=\frac{q_{4}-q_{1}}{m_{1}-m_{4}}, \\
y_{C}=\frac{m_{1} q_{4}-m_{4} q_{1}}{m_{1}-m_{4}}
\end{gathered}
$$

Now, standard substitutions and parallelism of lines give the following relationships: $m_{1}=m_{2}, q_{1}=q_{2}-m_{2} \times\left(R_{E}-R_{I}\right) ; m_{4}=m_{3}, q_{4}=q_{3}-m_{3} \times\left(R_{E}-R_{I}\right)$.

Therefore, after standard calculations, we get:

$$
\begin{gathered}
x_{C}=\frac{q_{3}-q_{2}}{m_{2}-m_{3}}-\left(R_{E}-R_{I}\right), \\
y_{C}=\frac{m_{2} q_{3}-m_{3} q_{2}}{m_{2}-m_{3}}
\end{gathered}
$$

By inserting the numerical values, we finally get $x_{C}=-19.5 \pm 2 ; y_{C}=1954 \pm 49$ pixels. The coordinates of the center of the cubicle no. 58 are $x_{58}=-19 ; y_{58}=1943$ 
pixels. The differences between the coordinates of the center and point $P_{1}$ is given by $\Delta x=\left|x_{58}-x_{C}\right|=|0.5 \pm 2|$, hence practically zero because 1 pixel corresponds to $8.9 \mathrm{~cm}$. Moreover, the difference along the $y$ - axis is also small: $\Delta y=\left|y_{58}-y_{C}\right|=|11 \pm 49|$ pixels, i.e., $|1 \pm 4.4| \mathrm{m}$. Therefore, point $P_{1}$ practically falls inside cubicle 58 , whose sides are $3 \mathrm{~m}$, or falls very close to it, within the errors of calculations of $\pm 4.4 \mathrm{~m}$, on the $y$ coordinate, which are large because of the small values of $\alpha$. If we consider the large distance between the center of cubicle 58 and the origin of the Cartesian coordinates (center of the mausoleum), equals to $\sqrt{1943^{2}+19^{2}}=1943.1$, i.e., $1943.1 \times 0.089 \approx 173 \mathrm{~m}$, the evidence that point $P_{1}$ falls on the cubicle 58 area is not by chance.

The coordinates of point $P_{2}$, intersection of the lines $r_{2}$ and $r_{3}$, are calculated similarly, and given by:

$$
\begin{gathered}
x_{T}=\frac{q_{3}-q_{2}}{m_{2}-m_{3}}, \\
y_{T}=\frac{m_{2} q_{3}-m_{3} q_{1}}{m_{2}-m_{3}}
\end{gathered}
$$

By comparing Equation (A7) to Equation (A6), we find:

$$
\begin{gathered}
x_{T}=x_{C}+R_{E}-R_{I}, \\
y_{T}=y_{C}
\end{gathered}
$$

The distance $y_{T}$ along the $y$ - axis is the same of $P_{1}$ (i.e., cubicle 58), while that along the -axis, $x_{T}$, is moved to the right of the difference of the radii of the mausoleum $R_{E}-R_{I}=(27.74-20.18) / 2=3.78 \mathrm{~m}$; therefore, $P_{2}$ is a little outside cubicle 58 . The details of the area of the intersections of the four straight lines are shown in Figure 12.

\section{References}

1. Apollonj Ghetti, B.M.; Ferrua, A.; Josi, E.; Kirschbaum, E. Esplorazioni Sotto la Confessione di San Pietro in Vaticano Eseguite Negli Anni 1940-1949; Libreria Editrice Vaticana: Vatican City, Vatican, 1951.

2. Guarducci, M. Le Reliquie di Pietro sotto la Confessione Della Basilica Vaticana: Una Messa a Punto; Coletti Editore: Roma, Italy, 1967; pp. 83-160.

3. Walsh, J.E. The Bones of Saint Peter; Collins Fount Paperbacks: Bungay, UK, 1982.

4. Ferrua, A. La criptografia mistica ed i graffiti Vaticani. Riv. Archeol. Cris. 1959, 35, 231-247.

5. Guarducci, M. La crittografia mistica e i graffiti vaticani: A proposito di una recensione del P. Antonio Ferrua. Archeol. Class. 1961, 13, 183-239.

6. Ferrua, A. Pietro in Vaticano. Civ. Cattol. 1984, 142, 573-581.

7. Guarducci, M. Pietro in Vaticano: Commento ad una recensione del p. Antonio Ferrua. Archeol. Class. 1984, 36, $266-298$.

8. Ferrua, A. La Tomba di San Pietro. Civ. Cattol. 1990, 1, 460-467.

9. Guarducci, M. I Graffiti Sotto la Confessione di San Pietro in Vaticano; Libreria Editrice Vaticana: Vatican City, Vatican, 1958; pp. 383-411.

10. Guarducci, M. Infondate riserve sulle reliquie di Pietro. Archeol. Class. 1968, 2, 352-373.

11. De Caro, L.; La Greca, F.; Matricciani, E. Saint Peter's First Burial Site According to Maria Valtorta's Mystical Writings, Checked Against the Archeology of Rome in the I Century. J. Multidiscip. Sci. J. 2020, 3, 366-400. [CrossRef]

12. Carcopino, J. Études D'Histoire Chrétienne; Albin Michel: Paris, France, 1953; pp. 230-232,261.

13. Mazzarino, S. L'impero Romano; Laterza: Roma, Italy, 2007; p. 893.

14. Barbero, A. Costantino il Vincitore; Salerno: Roma, Italy, 2016.

15. Bisconti, F. La memoria Apostolurum. In Pietro E Paolo—La Storia, Il Culto, La Memoria Nei Primi Secoli; Donati, A., Ed.; Electa: Milano, Italy, 2000; p. 64.

16. Mazzoleni, D. Pietro e Paolo Nell'Epigrafia Cristiana. In Pietro E Paolo—La Storia, Il Culto, La Memoria Nei Primi Secoli; Donati, A., Ed.; Electa: Milano, Italy, 2000; pp. 67-72.

17. Ferrua, A. Epigrammata Damasiana. In Sussidi Allo Studio Delle Antichità Cristiane, 2nd ed.; Pontificio Istituto di Archeologia Cristiana: Città del Vaticano, Vatican, 1942; pp. 142-144.

18. Liverani, P. Le Basiliche Romane Dedicate ai due Apostoli. In Pietro E Paolo—La Storia, Il Culto, La Memoria Nei Primi Secoli; Donati, A., Ed.; Electa: Milano, Italy, 2000; p. 54.

19. Nicolai, V.F. Le Catacombe Romane. In Lezioni di Archeologia Cristiana; Bisconti, F., Brandt, O., Eds.; Istituto Pontificio di Archeologia Cristiana, XXVII: Città del Vaticano, Vatican, 2014.

20. Krautheimer, R. Rome: Profile of a City 312-1308; Princeton University Press: Princeton, NJ, USA, 1980.

21. Fiocchi Nicolai, V.; Castiglia, G.; Brandt, O. (Eds.) Acta XVI Congressus Internationalis Archaeologiae Christianae, Romae 22-28.9, 2013: Costantino e i Costantinidi. L'Innovazione Costantiniana, le Sue Radici e i Suoi Sviluppi; Pontificio Istituto di Archeologia Cristiana: Vatican City, Vatican, 2016. 
22. Jastrzebowska, E. "Proprietari" dei mausolei imperiali a Roma nel IV secolo. Rend. Pontif. Accad. Romana Archeol. 2006, 79, 35-55.

23. Holloway, R.R. Constantine E Rome; Yale University Press: New Haven, CT, USA, 2004.

24. Logan, A. Who Built Old St Peter's? The Evidence of the Inscriptions and Mosaics. Vigiliae Christ. 2020, 75, 43-69. [CrossRef]

25. Liverani, P. La Basilica di S. Pietro in Vaticano. In Pietro e Paolo—La Storia, Il Culto, la Memoria nei Primi Secoli; Donati, A., Ed.; Electa: Milano, Italy, 2000; p. 56.

26. Caseau, B. Constantin et L'Encens. Constantin a-t-il Procédé à une Révolution Liturgique? In Costantino Prima e dopo Costantino/Constantine before and after Constantine; Bonamente, G., Lenski, N., Lizzi Testa, R., Eds.; Edipuglia: Bari, Italy, 2012; pp. 543-548.

27. Deichmann, F.W.; Tschira, A. Das Mausoleum der Kaiserin Helena und die Basilika del Heiligen Marcellinus und Petrus an der Via Labicana vor Rom. Jahrb. Dtsch. Archaeol. Lnstituts 1957, 72, 44-110.

28. Guyon, J. Le Cimetière Aux Deux Lauriers; École françaises de Rome: Rome, Italy, 1987; pp. 219-230.

29. Rasch, J.J. Das Mausoleum der Kaiserìn Helena in Rom und der "Tempio della Tosse", in Tivoli. Spätantike Zent. Rom Latium 1998, $3,3-50$

30. Sena Chiesa, G.; Arslan, A. Felix Temporis Reparatio; ET: Milan, Italy, 1992.

31. Deckers, J.; Seeliger, H.R.; Mietke, G. Die Katacombe «Santi Marcellino and Pietro». Repertorium der Malereien; Pontificio Istituto di Archeologia Cristiana: Città del Vaticano, Vatican, 1987.

32. Jones, M.W. Principles of Design in Roman Architecture: The Setting Out of Centralised Buildings. Pap. Br. Sch. Rome 1989, 57, 106-151. [CrossRef]

33. Marucchi, O. Le Catacombe Romane, 2nd ed.; Descleée, Lefebvre, E.C., Eds.; La Libreria Dello Stato: Rome, Italy, 1905; pp. 257-279.

34. Marucchi, O. La cripta storica dei Ss Pietro e Marcellino recentemente scoperta sulla via Labicana. Nuovo Bull. Arch. Crist. 1898, 4, 157-194.

35. Bosio, A. Roma Sotterranea; Berti, G., Contini, F., Eds.; Quasar Edizioni: Roma, Italy, 1632; p. 591D.

36. Giordani, B. Postille in margine al complesso dei santi Marcellino and Pietro al III miglio della via Labicana. Latomus 1996, $55,237-247$.

37. Mommsen, T. Gestorum Pontificum Romanorum, Libri Pontificalis, Pars Prior; Berolini-Apud Weidmannos: Berlin, Germany, 1898; Volume 1.

38. Duchesne, L. Le Liber Pontificalis: Texte, Introduction et Commentaire; Tome, I., Ed.; E. Thorin Publisher: Paris, France, 1886.

39. Donati, A. I Luoghi Della Memoria. In Pietro e Paolo_La Storia, Il Culto, La Memoria Nei Primi Secoli; Electa: Milano, Italy, 2000.

40. Kanzler, P. Relazione ufficiale degli scavi eseguiti dalla commissione di archeologia sacra nelle catacombe romane (1911-1912). Scavi nel cimitero dei santi Marcellino and Pietro sulla Via Labicana. Nuovo Bull. Arch. Crist. 1914, 46, 65-77.

41. Diehl, E. Inscriptiones Latinae Christianae Veteres (ILCV); Weidmannos: Berlin, Germany, 1924.

42. Ferrua, A. Memorie dei SS. Pietro e Paolo nell'Epigrafia. In "Saecularia Petri et Pauli", Studi di Antichità Cristiana, 28; Pontificio Istituto di Archeologia Cristiana: Città del Vaticano, Vatican, 1969; p. 145.

43. Marucchi, O. Catacombe Romane. Nuovo Bull. Arch. Crist. 1915, 21, 59-62.

44. De Rossi, G.B. Dell'epigrafe Memoria domni Petri et Pauli sopra un arco d'altare. Bull. Arch. Crist. 1877, 2, $106-107$.

45. Giuliani, R. Nuove acquisizioni dai restauri nelle catacombe romane dei SS. Marcellino e Pietro: Il programma decorativo dei cubicoli 9-13. Mitteilungen zur Christlichen Archäologie 2015, 21, 83-111. [CrossRef]

46. Wilpert, J. Le pitture recentemente scoperte nel cimitero dei ss. Marcellino e Pietro. Nuovo Bull. Archeol. Cris. 1900, 6, 85-97.

47. Nestori, A. Repertorio Topografico Delle Pittute Delle Catacombe Romane, 2nd ed.; Pontificio Istituto di Archeologia Cristiana: Città del Vaticano, Vatican, 1993; pp. 49-70.

48. Wilpert, J. Die Malereien der Katacomben Roms; Herder: Freiburg im Breisgau, Germany, 1903.

49. Bruno, L.; Rugnini, L.; Spizzichino, V.; Caneve, L.; Canini, A.; Ellwood, N.T.W. Biodeterioration of Roman hypogea: The case study of the Catacombs of SS. Marcellino and Pietro. Ann. Microbiol. 2019, 69, 1023-1032. [CrossRef]

50. De Feo, G.; Angelakis, A.N.; Antoniou, G.P.; El-Gohary, F.; Haut, B.; Passchier, C.W.; Zheng, X.Y. Historical and Technical Notes on Aqueducts from Prehistoric to Medieval Times. Water 2013, 5, 1996-2025. [CrossRef]

51. Deming, D. The Aqueducts and Water Supply of Ancient Rome. Groundwater 2020, 58, 152-161. [CrossRef] [PubMed]

52. Testini, P. Archeologia Cristiana; Edipuglia: Bari, Italy, 1980.

53. Valtorta, M. La Tomba di San Pietro; Centro Editoriale Valtortiano: Isola del Liri, Italy, 2013.

54. Valtorta, M. Quadernetti; Centro Editoriale Valtortiano: Isola del Liri, Italy, 2012. 